Int. J. Dev. Biol. 53: 215-229 (2009)

doi: $10.1387 / \mathrm{ijdb} .082644 \mathrm{jg}$

\title{
Dynamic alterations of linker histone variants during development
}

\author{
JAMES S. GODDE*,1 and KIYOE URA ${ }^{2}$ \\ ${ }^{1}$ Department of Biology, Monmouth College, Monmouth, IL, USA and \\ ${ }^{2}$ Division of Gene Therapy Science, Osaka University Graduate School of Medicine, Suita, Osaka, Japan
}

\begin{abstract}
The process of development can be viewed as a series of linker histone replacements which take place throughout spermatogenesis and oogenesis, as well as following fertilization or somatic nuclear transfer (SNT). Although few of the histone H1 variants in question have been shown to be essential for viability, the timing of their appearance as well as the affinity with which they are able to bind to chromatin seem to be important factors in their developmental role. A looser binding of linker histones to chromatin seems to correlate with the meiotic phases of gametogenesis and the establishment of a totipotent, as well as the maintenance of a pluripotent, state in early embryos, while tighter binding of linker histones to chromatin appears to be associated with the mitotic phases, as well as the increased levels of condensation that are required for the packaging of DNA into sperm. This latter process also involves the binding of certain basic non-histone proteins to DNA. While all proteins involved in chromatin compaction during development are highly basic in nature, in general they can be seen to change from lysinerich variants to arginine-rich ones, and back again. The fact that linker histone transitions are conserved across diverse metazoan species speaks of their importance in packaging DNA in a variety of ways during this crucial period.
\end{abstract}

KEY WORDS: histone H1, spermatogenesis, oogenesis, fertilization, SNT

\section{Chromatin structure}

The DNA in our cells is in a constant state of flux. Not only must the approximately two meter long length of DNA in human cells be packaged tightly in order to transmit it to other cells, it must also be periodically unpackaged in order to use any of the information stored in its code, such as during the processes of transcription and DNA replication. DNA is normally packaged in the cell in the form of chromatin. Chromatin consists of DNA wrapped around an octamer of the four core histone proteins: $\mathrm{H} 2 \mathrm{~A}, \mathrm{H} 2 \mathrm{~B}, \mathrm{H} 3$, and $\mathrm{H} 4$, to form a nucleosome. This arrangement was first described in 1974 by now Nobel Laureate Roger Kornberg, a finding that he recently reviewed and reflected upon (Kornberg, 1974; Kornberg and Lorch, 1999). One year later, the name «nucleosome» was coined to describe this fundamental unit of chromatin (Oudet el al., 1975). An open conformation of chromatin that is amenable to transcription or replication is commonly pictured as a string of nucleosomes linked together by connecting «linker» DNA, also known as a «beads on a string» arrangement, or simply a $10 \mathrm{~nm}$ fiber. The addition of a fifth «linker» histone, histone $\mathrm{H} 1$, which interacts with this connecting DNA was long pictured to be responsible for the conversion of this open arrangement to a closed one which is more refractory to cellular processes, a $30 \mathrm{~nm}$ fiber whose formation was dependent upon this final histone binding, although it has also been seen that this structure is further stabilized by a number of the core histone «tails» (Schwarz et al., 1996). These tails are features of the tripartite structure which makes up all histones, which contain a central globular domain surrounded by these $\mathrm{N}$ - and C-terminal extensions. The $30 \mathrm{~nm}$ fiber is then thought to go through a hierarchical series of «higher order» folding before it achieves the final folded state of the metaphase chromosome.

Histones are very basic proteins, owing to the large numbers of lysine and arginine residues which are primarily associated

Abbreviations used in this paper: ES, embryonic stem; FRAP, fluorescence recovery after photobleaching; MBT, mid-blastula transition; MMTV, mouse mammary tumor virus; PGC, primordial germ cells; SNT, somatic nuclear transfer.

\footnotetext{
*Address correspondence to: James S. Godde. Department of Biology, Monmouth College, 700 East Broadway, Monmouth, IL 61462 USA. Fax: +1-309-457-2226. e-mail: jgodde@monm.edu - web: http://department.monm.edu/biology/godde/index.htm

Published online: 2 February 2009.
}

ISSN: Online 1696-3547, Print 0214-6282 
with their tails (Ramakrishnan, 1997). Covalent chemical modification of these, as well as other amino acids, both in the tails and in the globular domain of histones is thought to modulate their binding to DNA as well as their compaction into chromatin, a concept referred to as the «histone code» (Strahl and Allis, 2000). Chemical modification of the histones, however, is not the only means that the cell uses to modulate their interaction with chromatin. All of the histones, with the exception of histone $\mathrm{H} 4$, are known to exist in structural variants which differ from one another in their primary sequence; these variants are often differentially expressed (Ausio, 2006). The number of linker histones variants, as well as their degree of divergence from one another, is much greater compared to the core histones (Brown, 2001). There are no less than eleven linker histone variants that have been found associated with mammalian cells, this is more than twice the number of variants found of any core histone (Ausio, 2006). The variants can be broadly classified as those commonly found in somatic cells (histones $\mathrm{H} 1.0-\mathrm{H} 1.5$, as well as $\mathrm{H} 1 . \mathrm{X}$ ) and those found associated with a particular tissue type. The somatic histones are also referred to as histones $\mathrm{H}_{1}^{\circ}, \mathrm{H} 1 \mathrm{a}, \mathrm{H} 1 \mathrm{c}, \mathrm{H} 1 \mathrm{~d}$, $\mathrm{H} 1 \mathrm{e}, \mathrm{H} 1 \mathrm{~b}$, and $\mathrm{H} 1 \mathrm{x}$, respectively, for a full discussion of linker histone nomenclature, see our recent review (Godde and Ura, 2008). Tissue-specific linker histones have been found both in the testes during spermatogenesis ( $\mathrm{H} 1 \mathrm{t}, \mathrm{H} 1 \mathrm{t} 2$, and HILS) as well as in the oocyte during oogenesis (H10o) (Ausio, 2006). In addition to their classification according to the cell type that they are expressed in, linker histone variants are also commonly classified as being either DNA replication dependent or independent in their expression patterns (Ausio, 2006). Most of the somatic histones are in this former class, being expressed only in S-phase, with the exception of $\mathrm{H}^{\circ}$ and $\mathrm{H} 1 \mathrm{x}$, which are expressed primarily during $G_{0}$ and $G_{1}$ phases, respectively. The tissue specific variants of $H_{1}$ also fit into this latter class, since their expression is also replication independent. This class of linker histones has also been referred to as «replacement» histones, since they serve to replace the replication dependent ones during various times in the cell cycle (Ausio, 2006). The time where histone replacement is most evident, as we will discuss, is during the process of development, which can be viewed in terms of the linker histone replacements which are taking place during specific stages (for an early review, see Khochbin and Wolffe, 1994). We will return to this discussion after we have expanded upon the in vivo function of histone $\mathrm{H} 1$ and its variants.

\section{Function of linker histones}

A wealth of in vitro data has demonstrated that histone $\mathrm{H} 1$ binds to the outside of the nucleosome to form a «chromatosome», in which it protects an additional 20 bp of DNA from cleavage by nucleases, compared to the $146 \mathrm{bp}$ of DNA which is wrapped around the octamer of core histones, in a process which normally serves as a prerequisite for the formation of the $30 \mathrm{~nm}$ fiber (Kornberg and Lorch, 1999). Linker histone binding was thus pictured as a means to achieve a general repression of cellular processes such as transcription, in view of its ability to block the access of the cellular machinery to folded chromatin. It thereby came as somewhat of a shock in 1995 when the $\mathrm{H} 1$ gene was knocked out in the ciliated protozoan Tetrahymena thermophila without an effect on cell viability or growth (Shen et al., 1995). This finding was then followed over the next decade by an expanding list of organisms that could live without histone $\mathrm{H} 1$, the deletion of which had only minimal effects. Since we have recently reviewed these studies in detail, we will not attempt to rehash all of the pertinent $\mathrm{H} 1$ deletion studies here, and the reader is referred to our previous work (Godde and Ura, 2008). We will, however, reexamine some of these studies in terms of their relation to the developmental process. While the deletion of linker histones has been shown to be without an effect on the viability of a number of organisms, the existence of some role for them in the developmental process remains unquestionable. Certain clues to their precise role during development have been brought to light by the genetic studies to be described below.

A number of lower eukaryotes which lack complex developmental processes have been found to survive in the absence of histone $\mathrm{H} 1$ with few discernable effects. This includes Tetrahymena, along with three fungal species: Saccharomyces cerevisiae, Aspergillus nidulans, and Ascobolus immersus (Ushinshy et al., 1997; Ramon et al., 2000; Barra et al., 2000). The latter species is of most interest to this discussion, since the authors did note that $\mathrm{H} 1$ deletion led to a hypermethylation of DNA at specific sites, primarily those which were found to have some degree of methylation in the wild-type strains, a link that has also been observed in higher eukaryotes (Barra et al., 2000). $\mathrm{H} 1$ deletion studies have proved to be more difficult in higher eukaryotes, however, due to the presence of multiple $\mathrm{H} 1$ subtypes encoded by separate genes, along with a little-understood compensatory mechanism which up-regulates the expression of remaining subtypes so that near normal ratios of linker histones to nucleosomes are maintained (Sirotkin et al., 1995). This compensatory mechanism, although first described in animals, is also present in plants, as was seen when the levels of two major histone $\mathrm{H} 1$ variants were decreased in transgenic tobacco plants (Prymakkowska-Bosak et al., 1999). In these studies, the H1-depleted plants were shown to exhibit male sterility, along with aberrations in flower development which could be linked to changes in the temporal expression of specific genes. The link between histone $\mathrm{H} 1$ and the maintenance of specific methylation patterns in DNA was further supported by studies from this same group, which were subsequently able to achieve a $>90 \%$ reduction in linker histone levels in Arabidopsis thaliana (Wierzbicki and Jerzmanowski, 2005). These mutants displayed a number of developmental aberrations, including the formation of irregular leaves and changes in both the timing and morphology of flower production, which were reminiscent of Arabidopsis plants known to display DNA hypomethylation in specific regions. As expected, the authors were able to demonstrate altered patterns of DNA methylation in the $\mathrm{H} 1$ mutant strains (Wierzbicki and Jerzmanowski, 2005).

A majority of the genetic studies demonstrating the importance of histone $\mathrm{H} 1$ in animals have been performed in mice, many of which have been undertaken by the laboratory of Arthur Skoultchi. Initial studies by this group determined that single gene knockouts of various $\mathrm{H} 1$ variants produced no detectable effects, probably due to the aforementioned compensatory mechanism, demonstrating in this case that neither $\mathrm{H}_{1}^{\circ}$ nor $\mathrm{H} 1 \mathrm{t}$ were indispensable in the mouse (Sirotkin et al., 1995; Lin et al., 2000). Two subsequent studies by different laboratories confirmed this latter finding concerning the dispensability of histone H1t (Drabent et al., 2000; Fantz et al., 2001). A review of histone $\mathrm{H} 1$ diversity written 
around this time put forth a theory that the timing of histone variant expression may, in fact, be more important than their actual primary sequence (Khochbin, 2001). This would account for the compensatory mechanism's ability to replace a specific $\mathrm{H} 1$ subtype by the up-regulation of a similar gene. This mechanism was therefore put to the test by the deletion of two genes simultaneously: knocking out $\mathrm{H} 1^{\circ}$, along with either $\mathrm{H} 1.2, \mathrm{H} 1.3$, or $\mathrm{H} 1.4$, however, still did not result in a change in the ratio of linker histone to nucleosomes in the chromatin of the double mutants and was still without discernable effect (Fan et al., 2001). It was only when $\mathrm{H} 1 \mathrm{t}$, along with the histone that was found to be mainly responsible for its replacement in single mutants, histone $\mathrm{H} 1.1$, was deleted that a $25 \%$ reduction in the normal ratio of $\mathrm{H} 1$ to nucleosomes was achieved and that some subtle effects in the gene expression of mutant cells could be demonstrated (Lin et al., 2004). It was not until triple mutants $(\mathrm{H} 1.2, \mathrm{H} 1.3$, and $\mathrm{H} 1.4)$ were created in mice that the normal ratio of $\mathrm{H} 1$ to nucleosomes was reduced by $50 \%$, resulting in severe developmental defects (Fan et al., 2003). Embryos which carried this triple mutation usually died by midgestation, exhibiting a broad range of defects. A follow-up paper described the monitoring of changes in gene expression which may have led to the observed defects in these mutants using microarrays (Fan et al., 2005). Here, it was shown that 29 genes in mice exhibited at least a 2-fold difference in expression between mutants and the wild type, among which the authors noticed an overrepresentation of imprinted genes, as well as those associated with the X-chromosome. In all, nearly one third of the affected genes were known to be normally regulated by changes in DNA methylation (Fan et al., 2005). Thus, the links between histone $\mathrm{H} 1$ and DNA methylation have been demonstrated across three kingdoms: fungi, plants, and animals (Barra et al., 2000; Wierzbicki and Jerzmanowski, 2005; Fan et al., 2005). Since these links, as well as the phenotypes of both plants and animals with severe reductions in their level of linker histones, all point to a central role for histone $\mathrm{H} 1$ and its variants during development, we will next describe the various developmental stages, along with the corresponding changes in $\mathrm{H} 1$ subtype which accompanies them.

\section{Spermatogenesis}

Spermatogenesis is the process by which spermatogonial stem cells go through a series of morphological changes in order to produce the differentiated haploid cells known as spermatozoa (Pradeepa and Rao, 2007). The process can be divided into three stages: 1) the mitotic, or proliferative, phase, in which spermatogonial stem cells undergo multiplication and renewal, 2) the meiotic phase, in which the genetic material of spermatocytes is recombined and segregated, and 3 ) the differentiation, or spermiogenic, phase, in which spermatids elongate and transform into mature spermatozoa (Russell et al., 1990; Pradeepa and Rao, 2007). We will discuss the linker histone complement of each of these stages in turn.

\section{Mitotic phase}

Primordial germ cells, or PGCs, that migrate to the developing male testis become arrested in the $G_{1}$ phase of the cell cycle until the birth of the organism. These spermatogonial stem cells must then undergo a number of mitoses as they differentiate to form spermatocytes. In the rat, spermatogonia divide approximately nine times a week (Russell et al., 1990). Spermatogonia are further classified into either Type A, Intermediate, or Type B, depending on the levels of chromatin that can be found lying along the inner aspect of the nuclear envelope using microscopy, exhibiting either none, a moderate amount, or a large amount, respectively (Russell et al., 1990). Spermatogonia have been found to contain a compliment of somatic linker histones, namely H1.1 and H1.2 (Meistrich et al., 1985; Fig. 1). Knocking out the $\mathrm{H} 1.1$ gene, in agreement with the studies described above, did not have an effect on spermatogenesis (Rabini et al., 2000). Instead, it was shown that levels of $\mathrm{H} 1.2$ increased in the mutants, along with that of $\mathrm{H} 1.3$ and/or $\mathrm{H} 1.4$. Interestingly, RNA-mediated interference of $\mathrm{H} 1.1$ in Caenorhabditis elegans affected germline proliferation and differentiation, often leading to mutant sterility, but this was true of hermaphrodites only, not of males (Jedrusik and Schulze, 2001). This was not, however, the case when the expression of one of the other five somatic $\mathrm{H} 1$ subtypes was disrupted.

A number of in vitro studies have been performed to compare the ability of different histone $\mathrm{H} 1$ subtypes to condense short arrays of nucleosomes (De Lucia et al., 1994; Khadake and Rao, 1995; Talasz et al., 1998). One of these studies used circular dichroism to gauge the effect of linker histone binding to $\mathrm{H} 1$ depleted chromatin and concluded that histone $\mathrm{H} 1.1$ had the highest condensation ability of all the subtypes tested (De Lucia et al., 1994). Another study used similar methods to conclude that the
Fig. 1. Morphological changes during spermatogenesis, along with known linker histone transitions. An overview of the major developmental changes which occur during the formation of sperm in mice. For simplicity, not all stages are shown. Width of bar corresponding to a particular H1 subtype or non-histone variant is approximate for the amount of each protein that has been detected in the various stages shown. Histone and non-histone variants are labeled; somatic H1 levels are indicated by a black bar, H1t levels by a gray bar, H1T2 levels by a green bar, HILS1 as well as TP2 levels by a blue bar, and P2 levels by an orange bar. Levels of protein are only approximate, based on sources which are referenced in the text. Illustration by Justin Godde. 
ability of histone $\mathrm{H} 1.1$ to condense chromatin was roughly the same as a mixture of subtypes purified from rat liver (Khadake and Rao, 1995). A third experiment studied the ability of increasing amounts of histone subtypes to aggregate chromatin arrays which had been reconstituted in vitro onto a specific DNA sequence and confirmed that, while the chromatin condensing activities of $\mathrm{H} 1.1$ were roughly equivalent to a mixture of $\mathrm{H} 1$ subtypes from liver tissue, they were higher than that of a mixture of subtypes obtained from testes, as well as of purified histones $\mathrm{H} 1.2, \mathrm{H} 1.5$, and H1t (Talasz et al., 1998). Since mitotic chromosomes represent the most condensed state in the cell that DNA can obtain, it is not surprising that histone $\mathrm{H} 1$ subtypes known for their chromatin condensation abilities predominate during the mitotic phase of spermatogenesis. At the end of the mitotic phase, Type B cells divide to form preleptotene, or resting, spermatocytes (Russell et al., 1990; Fig. 1).

\section{Meiotic phase}

Resting spermatocytes can be microscopically differentiated from Type B spermatogonia by observing their chromatin. The former appear slightly smaller than the latter, having less chromatin situated along the nuclear envelope, as well as less protruding inward toward the center of the nucleus (Russell et al., 1990). These cells will then undergo two meiotic divisions, the first of which forms secondary spermatocytes and the second of which produces spermatids. Meiosis I is characterized by an exceptionally long prophase, lasting about three weeks in the rat, the five stages of which can been discriminated from each other by the appearance of the chromatin (Russell et al., 1990). In leptotene cells, the nuclei lose their peripheral chromatin and form condensed meiotic chromosomes, which are visible as fine chromatin threads (Russell et al., 1990). The chromosomes then pair along their length in zygotene cells, and remain paired for an extended pachytene stage that lasts for nearly two weeks in the rat (Russell et al., 1990). It is during this stage that homologous recombination, or crossing over, takes place, while the spermatocyte cells can be seen to rapidly increase in size as their enlarged nuclei change in appearance from round to ovoid in shape (Russell et al., 1990). It is midway through pachytene that the linker histone type undergoes its first replacement in spermatogenesis (Fig. 1).

The presence of testis-specific linker histones was first reported over 30 years ago. In 1975, the same year the nucleosome got its name, frog testes were reported to contain a fast migrating $\mathrm{H} 1$ variant that was not found in other tissues (Alder and Gorovsky,

\section{TABLE 1}

\section{CHARACTERISTICS OF LINKER HISTONES AND THE RESULT OF THEIR DEPLETION IN MICE}

\begin{tabular}{llllll} 
H1 variant & Size (a.a.) & K:R & Depletion Result & Method & Reference \\
\hline somatic* & $212-223$ & 16 & Developmental defects & K.O. (triple) & Fan et al., 2003 \\
H1t & 209 & 2.9 & None detected & K.O. & Lin et al., 2000 \\
H1T2 & 398 & 0.6 & Reduced fertility & K.O. & Martianov et al., 2005 \\
HILS1 & 170 & 1.6 & Reduced sperm mobility? & n.d. & Jedrzejczak et al., 2007 \\
TP2 & 117 & 0.7 & Smaller litters & K.O. & Zhao et al., 2001 \\
P2 & 107 & 0.08 Heterozygote is sterile & K.O. & Cho et al., 2001 \\
H100 & 304 & 2.3 & Metaphase I arrest & antisense MO & Furuya et al., 2007 \\
\hline
\end{tabular}

Particular $\mathrm{H} 1$ variants discussed in this review, along with their size, lysine to arginine ratio (K:R), and result of depletion in mice. Methods of depletion include: K.O. (genetic knockout), Antisense MO (morpholino oligonucleotides), or n.d. (not done). TP2 and P2 are included in this chart, even though they are not classified as linker histones. *somatic $\mathrm{H} 1$ denotes averaging of data from $\mathrm{H} 1.1-\mathrm{H} 1.5$, the triple knockout referred to is that of $\mathrm{H} 1.2-\mathrm{H} 1.4$ only.
1975). The same year, this finding was expanded to rat, rabbit, monkey, and mouse (Shires et al., 1975). Within five years, this protein had been isolated from rat and its amino acid content analyzed. The isolated variant was named histone $\mathrm{H} 1 \mathrm{t}$, and its relationship to meiosis was noted, along with its characteristic enrichment in arginine (Seyedin and Kistler, 1980). Linker histones, being quite basic proteins, normally contain lysine as their most prevalent amino acid. While lysine had been found to be present at almost a twenty fold higher amount than arginine in other $\mathrm{H} 1$ variants, it was found to be only three fold enriched in $\mathrm{H} 1 \mathrm{t}$ (Seyedin and Kistler, 1980; Table 1). When the amino acid sequence of histone $\mathrm{H} 1 \mathrm{t}$ was determined (in this case from boar), it was found that most of the replacement of lysine with arginine occurred in the C-terminal tail, which was also seen to be shorter than the comparable domain of somatic H1s (Cole et al., 1984; Fig. 2). As we shall see, the process of linker histone replacement which takes place during spermatogenesis could also be characterized as a progressive increase in arginine-rich proteins which is accompanied by the steady decline, and eventual disappearance, of the lysine rich ones (Table 1; Fig. 1).

A wealth of collected evidence suggests that histone $\mathrm{H} 1 \mathrm{t}$ both binds to DNA with a lower affinity than somatic $\mathrm{H} 1$ as well as condenses chromatin to a lesser extent upon binding (De Lucia et al., 1994; Khadake and Rao, 1995; Talasz et al., 1998; Wellman et al., 1999; De et al., 2002; Ramesh et al., 2006). Significantly, certain lysine rich repeats, $(\mathrm{S} / \mathrm{T}) \mathrm{P}(\mathrm{K} / \mathrm{A}) \mathrm{K}$, that are known for their interaction with DNA as well as for acting as sites of phosphorylation associated with the formation of condensed chromatin, were found to be absent in histone H1t (Cole et al., 1984). The three in vitro studies discussed above in the context of $\mathrm{H} 1.1$ binding to chromatin arrays all agreed that $\mathrm{H} 1 \mathrm{t}$ was a poor condenser of chromatin, relative to the somatic $\mathrm{H} 1$ subtypes (De Lucia et al., 1994; Khadake and Rao, 1995; Talasz et al., 1998). Furthermore, when the affinity of histone $\mathrm{H} 1 \mathrm{t}$ for naked DNA was compared to that of $\mathrm{H}^{\circ}$, it was seen that the former occupied a smaller binding site as well as exhibited binding constants which were one to two orders of magnitude lower than the latter histone (Wellman et al., 1999). Ever since the amino acid sequence of H1t was first determined, it was suggested that the $\mathrm{C}$-terminal tail would prove to be the most critical determiner of this histone's interaction with the nucleosome. Susan Wellman, from the above referenced article soon went on to collaborate with another research group at her institution to create recombinant chimeric histones which contained various combinations of the three histone domains, taken from either $\mathrm{H} 1 \mathrm{t}$ or $\mathrm{H}^{\circ}{ }^{\circ}$. Investigations of chromatin folding using fluorescence microscopy, as well as functional studies of the inhibition to DNA replication afforded by the various constructs both showed that the $\mathrm{C}$-terminal tail region was the domain which was responsible for the different properties exhibited by these two histones (De et al., 2002). The C-terminal histone tail, however, may not be the only determinant of reduced $\mathrm{H} 1 \mathrm{t}$ binding to chromatin. Recently, Satyanarayana Rao's group, which is referenced above, showed that a single amino acid change in the globular domain of histone $\mathrm{H} 1 \mathrm{t}$ can increase its affinity for nucleosomes to comparable levels with histone $\mathrm{H} 1.3$, the two histones normally differing in globular domain sequence at this single location (Ramesh et al., 2006).

All of these in vitro studies point to histone $\mathrm{H} 1 \mathrm{t}$ forming less compact chromatin with a more open arrangement when it is 
bound. Such a chromatin arrangement might be particularly amenable to the genetic recombination which is known to take place during this stage of spermatogenesis. This is not to say that $\mathrm{H} 1 \mathrm{t}$ is the sole linker histone variant found during the meiotic phase. In prepachytene spermatocytes, histone $\mathrm{H} 1.1$ has been estimated to comprise about $70 \%$ of the linker histone in the cell (Lennox and Cohen, 1984). These levels are then seen to steadily decrease at the beginning of this phase, although the histone does not disappear entirely until the middle of the post meiotic phase (Chuirkov et al., 2004). Levels of $\mathrm{H} 1 \mathrm{t}$, on the other hand, are seen to rapidly increase during the pachytene stage until it becomes the predominant linker histone (Meistrich et al., 1985). Two of the studies which knocked out histone $\mathrm{H} 1 \mathrm{t}$ in mice measured the amount of both $\mathrm{H} 1.1$ and $\mathrm{H} 1.2$ in mutant testes and found that levels of the two had risen from about $30-40 \%$ of the $\mathrm{H} 1$ compliment to approximately $40-50 \%$ for the former and from around $15-20 \%$ to about $30 \%$ for the latter (Lin et al., 2000; Drabent et al., 2000). The authors went on to surmise that the depletion of $\mathrm{H} 1 \mathrm{t}$ may be tolerated in spermatocyte chromatin due to the maintenance of this less compact chromatin arrangement in the mutants (Drabent et al., 2000). It was not investigated whether the $\mathrm{H} 1 \mathrm{t}$ mutants had defects in genetic recombination, something that would not be expected to produce an obvious phenotype but could, instead, ultimately have longterm effects on the genetic diversity of a given population.

Following the long pachytene stage, the next two stages of prophase I occur fairly rapidly. First, the diplotene stage is characterized by the separation of the chromosome pairs, except at chiasmata; then, during diakinesis, the chromosomes become even more condensed and the chiasmata are forced to move laterally, toward the tips of the chromosomes (Russell et al., 1990). Similarly, metaphase, anaphase, and telophase of meiosis I are completed quite rapidly as well, the first meiotic division culminating with the formation of secondary spermatocytes. These spematocytes are similar in appearance to the primary spermatocytes from which they arose, with the exception of being $30-40 \%$ larger and containing heterochromatin which appears somewhat fuzzy, as opposed to being fairly distinct (Russell et al., 1990). Meiosis II then takes place, again quite rapidly, to produce haploid spermatids from the secondary spermatocytes.

\section{Differentiation phase}

In the rat, three more weeks are required for spermatids to differentiate into mature spermatozoa, a process which does not

\section{A}
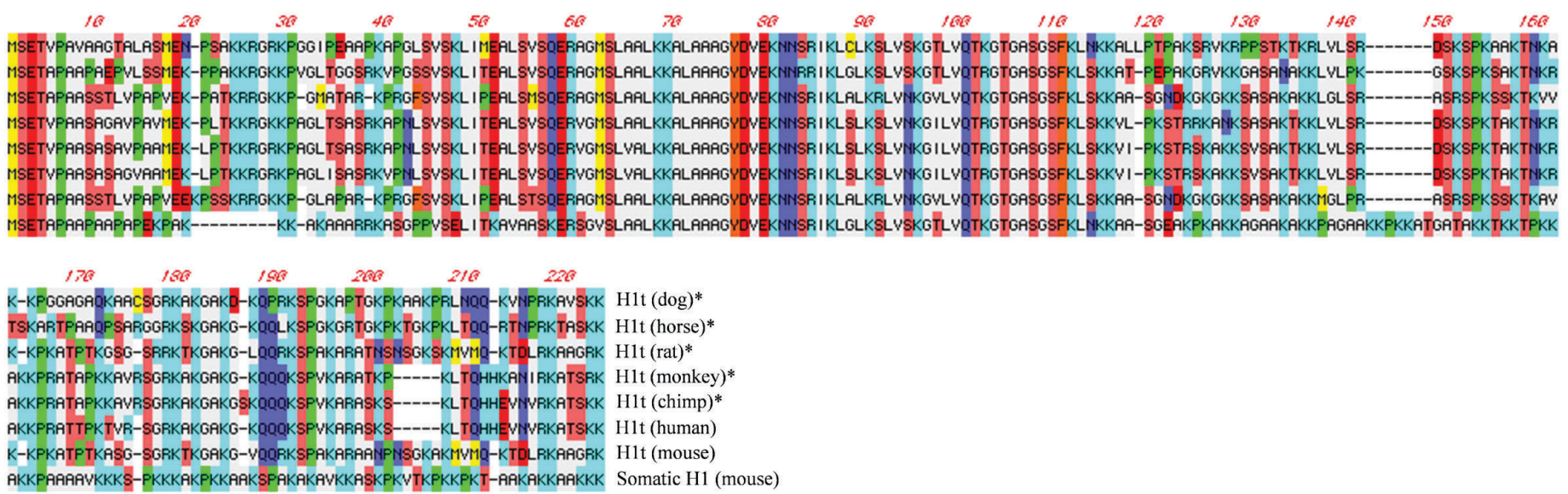

B
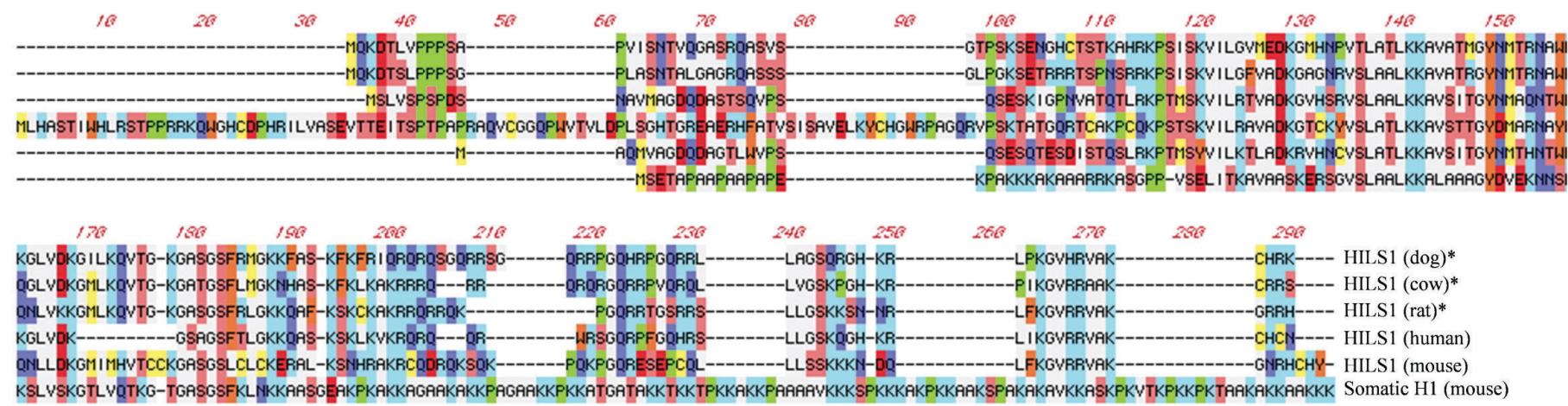

Fig. 2. Multiple alignment of protein sequences from histone H1t and HILS1. Protein sequences from a variety of species aligned using a ClustalW alignment. Sequences from either (A) H1t or (B) HILS were aligned to a consensus sequence formed from somatic H1.1-H1.5. An asterisk denotes hypothetical proteins whose assignments are tentative. Alignment was performed using MacVector 7.2.2 program using default ClustalW settings. The accession numbers of the protein sequences used are, from top to bottom: (A) XP_545388, XP_001497342, NP_036711, NP_001074230, XP_527257, NP_005314, NP_034506; (B) XP_537672, XP_873430, NP_001103035, AAQ23050, NP_061262. 
require any further cell division but is accompanied by a burst of transcription (Russell et al., 1990). This spermiogenic process is further subdivided into 19 steps in the rat but only 16 in the mouse, in which round spermatids undergo a number of morphological steps to become elongated spermatids (Russell et al., 1990). While the cell transformations which occur during this phase include the development of both the flagellum as well as the acrosome (a golgi-derived sac of enzymes found in the sperm head), in addition to the elongation and significant elimination of the cytoplasm, this review will continue to concern itself primarily with the changes which take place in chromatin structure as well as linker histone type. During the elongation of round spermatids, it was recently shown that another histone $\mathrm{H} 1$ subtype, aptly called H1T2, appears and gradually replaces $\mathrm{H} 1 \mathrm{t}$ (Martianov et al., 2005; Tanaka, H., et al., 2005; Figs. 1 \& 3). H1T2 is distinctive in that it is even more rich in arginine that $\mathrm{H} 1 \mathrm{t}$, with almost twice as many arginine residues as lysines, and, in contrast to $\mathrm{H} 1 \mathrm{t}$, there are 14 potential phosphorylation sites (Tanaka, H., et al., 2005; Table 1). Phylogenetic analysis showed that this histone is more closely related to histone $\mathrm{H} 1^{\circ}$ than it is to $\mathrm{H} 1 \mathrm{t}$ (Tanaka, $\mathrm{H}$., et al., 2005). H1T2 expression is first detected in step 4 of differentiation, after round spermatids have begun to take on an ovoid shape in preparation for elongation (Martianov et al., 2005; Russell et al., 1990; Fig. 1). This linker histone specifically localizes to chromatin in the apical pole just beneath the developing acrosome, opposite from where the flagella will begin to sprout around step 8. Expression continues in the spermatid until step 13 , when the cell has obtained an elongated shape, but the cytoplasm remains somewhat ovoid in shape, prior to undergoing significant elimination (Tanaka, H., et al., 2005; Russell et al., 1990; Fig. 1).

Deletion of the H1T2 gene was found to lead to severely reduced fertility in males, accompanied by morphological abnormalities such as residual cytoplasm, acrosome detachment, and fragmented DNA (Martianov et al., 2005). These morphological abnormalities were severe enough to prevent fertilization, both in vivo and in vitro, but mutant sperm remained capable of fertilizing eggs by intracytoplasmic injection ( $\mathrm{H}$. Tanaka et al., 2005). Subsequent studies investigated the mechanisms that led to the polar placement of H1T2-rich chromatin and found that it was not dependent on the formation of the acrosome itself but was sensitive to mutations in proteins known to play a role in the organization of nuclear chromatin (Catena et al., 2006). In these mutants, the H1T2 localized in a bipolar fashion, preventing proper elongation of the spermatids.

In step 9, shortly after the flagella become visible, a third testisspecific $\mathrm{H} 1$ subtype, HILS1 (H1-like protein in spermatids 1), whose expression overlaps with that of $\mathrm{H} 1 \mathrm{~T} 2$, is seen to be expressed in elongating spermatids (Yan et al., 2003; Iguchi et al., 2004; Fig. 1). HILS1 was found to have a lysine to arginine ratio which was intermediate between the two other sperm-specific linker histones, and phylogenetic analysis of the HILS1 gene showed that, unlike $\mathrm{H} 1 \mathrm{~T} 2$, it is closely related to $\mathrm{H} 1 \mathrm{t}$ (Table 1; Fig. 2; Yan et al., 2003). The appearance of HILS1 coincides with the disappearance of histone $\mathrm{H} 1 \mathrm{t}$, in addition to that of the core histones which have been present during spermatogenesis (Yan
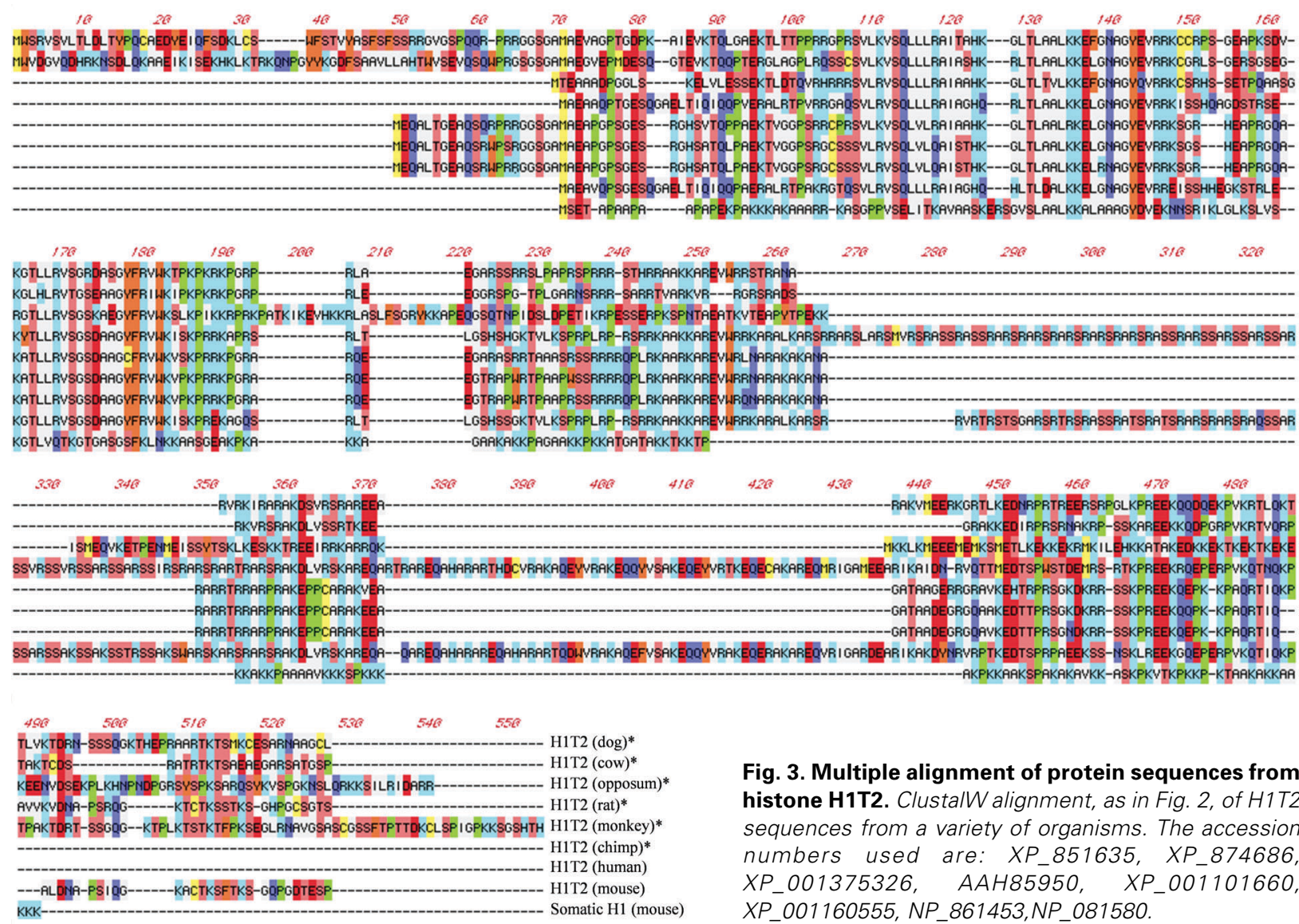

Fig. 3. Multiple alignment of protein sequences from histone H1T2. ClustalW alignment, as in Fig. 2, of H1T2 sequences from a variety of organisms. The accession numbers used are: XP_851635, XP_874686, $X P_{-} 001375326, \quad A A H 85950, \quad X P_{-} 001101660$, $X P \_001160555, N P \_861453, N P \_081580$. 
et al., 2003). Although HILS1 has been shown to bind to reconstituted nucleosomes in vitro, is does so with a lower affinity, compared to histone H1.1 (Yan et al., 2003). Despite this, its lack of significant overlap with core histones during development suggests that HILS1 has the distinction of being the only linker histone that does not normally coexist with nucleosomes. Although the deletion of HILS1 has not been reported in mammals, a disruption of Mst77F, a purported homolog in Drosophila melanogaster, speaks to its importance in spermatogenesis (Raja and Renkawitz-Pohl, 2005). Mst77F mutant males are sterile and can be seen to retain round nuclei in their spermatids, instead of elongated ones. In addition, the levels of HILS1 have been found to be significantly reduced in human males suffering from reduced sperm motility (Jedrzejczak et al., 2007).

What form does DNA take at this point, if not found complexed into canonical nucleosomes? Around the time $\mathrm{H} 1 \mathrm{t}$ and the core histones disappear, a set of small basic proteins, including transition protein 1 (TP1 of TNP1) and transition protein 2 (TP2 or TNP2), appear in the spermatids (Oko et al., 1996, Fig. 1). These proteins are seen to be quite arginine rich, with ratios between the two basic amino acids comparable to that of H1T2 (Table 1; Yu et al., 2000). TP2 is $13 \mathrm{kDa}$ in size, approximately the size of one of the core histones, while TP1 is less than half that molecular weight. It has been suggested that the latter is involved in histone removal, while the former is involved in chromatin condensation (Zhao et al., 2001). In fact, TP2 can be seen to co-localize in the cell with HILS1 at this point (Yan et al., 2003). The transition proteins begin the alteration between the chromatin that has existed up until this point and a highly condensed, uniformly dense mass that forms beneath the acrosome. Upon the appearance of the transition proteins, transcription in the spermatid can be seen to cease and chromatin takes the form of a smooth fiber (Oko et al., 1996). The DNA will eventually be complexed into its most dense form that is found associated with any cell and be packaged into a volume that is less than $5 \%$ that of a somatic cell nucleus, in preparation for its transport to the oocyte (Cho et al., 2001). By step 13 of the differentiation phase, when transcription of $\mathrm{H} 1 \mathrm{~T} 2$ has been turned off, and the protein can be seen to disappear from the cell, HILS1 is, presumably, the only linker histone which remains in the cell, albeit at relatively low levels at this point (Fig. 1). Basic proteins that can be extracted from the nucleus at this stage have been estimated to consist of $62 \%$ TP1, $28 \%$ TP2, and only 1\% histone (Yu et al., 2000).

Transition proteins are not only similar to histones in their size, localization, and basicity, they also seem to display a similar system of compensatory regulation which complicates genetic deletion studies. When the gene for TP1 was deleted in mice, it was shown to produce a number of infertile males with subtle abnormalities in sperm morphology which often led to reduced sperm motility (Yu et al., 2000). More drastic effects may have been prevented, however, by the up-regulation of TP2, which was found to constitute $91 \%$ of the basic protein compliment of the nucleus in step 13 spermatids, compared to $<4 \%$ histone (Yu et al., 2000). Deletion of the TP2 gene gave even less drastic phenotypes: mutant mice were fertile but did tend to produce smaller litters, while microscopy revealed some incomplete chromatin condensation as well as tail abnormalities (Zhao et al., 2001; Table 1). Levels of TP1 in TP2-null mice were seen to increase to $87 \%$ of the basic nuclear proteins (Zhao et al., 2001).
The subsequent creation of double-null mutants in these transition proteins led to observable defects in chromatin condensation, as well as sterility in affected mice (Zhao et al., 2004). However, as in the case of the H1T2 deletion, the sperm still produced efficient fertilization via intracytoplasmic injection (Zhao et al., 2004).

During the final few steps of the differentiation phase of spermatogenesis, the transition proteins are replaced by a final set of basic proteins called protamines to prepare the DNA for delivery to an oocyte. Protamine 1 (P1 or PRM1) and protamine 2 (P2 or PRM2) are almost exactly the same molecular weight as TP1 and TP2, respectively, but are composed of $>50 \%$ arginine, with little or no lysine present (Lewis et al., 2004; Table 1; Fig. 1). While none of these four proteins are classified as histones, it has been demonstrated that the emergence of protamines in chordates was likely the result of a frameshift mutation in the tail of a bone fide histone $\mathrm{H} 1$ which converted the lysine-rich protein to an arginine-rich one (Lewis et al., 2004). While no such phylogenetic link has been established for the transition proteins, it appears that they are a fairly recent addition to the basic nucleoprotein complement of sperm, as fish and birds lack this class of proteins completely and can be seen to undergo a transition directly from histone-containing chromatin to protamine-associated DNA (Yu et al., 2000). In contrast, annelids and echinoderms maintain the nucleosomal conformation of chromatin in sperm and lack both transition proteins as well as protamines (Raja and RenkawitzPohl, 2005). Following step 14 in mice, protamines can be seen to have almost completely replaced the transition proteins, making up $74 \%$ of the basic protein extractable from spermatids, compared to only $22 \%$ transition proteins and $<4 \%$ histones ( $Y u$ et al., 2000). During this time, the DNA forms a fiber around which the protamines wrap, which comes to resemble a stack of doughnuts (Raja and Renkawitz-Pohl, 2005). This ultra-condensed conformation of the DNA is important for both sperm hydrodynamics as well as protecting the genome from physical and chemical damage as it journeys out into the world. From step 15 on, HILS1, as well as the two transition proteins, are no longer detectable in the nucleus (Yan et al., 2003, Fig. 1). In contrast to linker histones as well as the transition proteins, disruption of a single allele of either protamine discussed here demonstrated haploinsfficiency and led to the production of sterile males (Cho et al., 2001). Morphological abnormalities such as sperm with their flagella tightly wrapped around their heads or having elongated heads with reduced ventral flexure were common in mutants, as were indicators of incomplete chromatin condensation (Cho et al., 2001). Finally, after 1.5 to 2 months of development, the spermatids complete step 16 in the mouse and are ready to be released as mature spermatogonia.

\section{Broadening our base}

Since this review has focused on mammalian development, namely that of the rat and mouse, up until this point, we will attempt to continue to describe the following events with these organisms in mind. However, discussion of linker histone transitions during both oogenesis and embryogenesis will necessitate the inclusion of data from a much wider array of organisms. While we have pointed out earlier that it has been over 30 years since the first testis-specific linker histone was reported in both rats and 
mice, it took until the early 21 st century before the first oocytespecific linker histone was described in mice, the first in any mammalian system (Tanaka et al., 2001). Ironically, the first description of an oocyte-specific linker histone actually predated the original discovery of a testis-specific $\mathrm{H} 1$ subtype, when a «cleavage stage» histone was characterized in sea urchin (Ruderman and Gross, 1974). This was soon followed by descriptions of histone subtype switches during embryo development in such diverse organisms as the mud snail, Ilyanassa obsoleta; two frogs, Xenopus laevis and Bufo japonicus; the midge, Chironomus thummi; mouse; the zebrafish, Danio rerio; and, finally, in humans as well (Flenniken \& Newrock, 1987; Smith et al., 1988; Ohsumi and Katagiri, 1991; Trieschmann et al., 1997; Tanaka et al., 2001; Wibrand and Olsen, 2002; Muller et al., 2002; Tanaka et al., 2003, Fig. 4). Confusingly, most of these oocyte-specific linker histones were called by a different name in the literature, including $\mathrm{CS}-\mathrm{H} 1$, $\mathrm{B} 4, \mathrm{H} 1 \mathrm{X}, \mathrm{H} 1 \mathrm{I}-1, \mathrm{H} 1 \mathrm{M}$, and $\mathrm{H} 1 \mathrm{Oo}$ (which has recently been altered to $\mathrm{H} 1$ foo to denote its status as a member of the histone $\mathrm{H} 1$ «family», instead of a bone fide histone $\mathrm{H} 1$, a renaming scheme that has also been applied to its close relative, $\mathrm{H} 1^{\circ}$ ). Since studies of oocyte-specific histones have primarily focused on Xenopus laevis, in which we find histone B4, this will be the most common organism which we now introduce into our discussion.

\section{Oogenesis}

While the process of spermatogenesis is quite similar throughout all vertebrates, the details of oogenesis differ considerably, depending on the reproductive strategies of the organism in question (Carlson, 1996). The development of oocytes does share certain similarities with spermatogenesis, however, con- sisting of similar stages up until the differentiation phase, which is not found in oogenesis, per se. This is not to say that oocytes do not undergo differentiation but that they do so concurrently with their meiotic phase, although oocyte development does lack the scope of morphological changes which must take place in sperm. The oocyte is easily the largest and most complex cell that is produced by an animal, and has the distinction of being the only cell for which differentiation is not a terminal condition (Clarke et al., 1998). Perhaps because of this lack of a separate differentiation phase, the linker histone transitions which take place during oogenesis are not as complex as those observed for spermatogenesis, involving only the replacement of somatic linker histones with oocyte-specific ones. As we have seen, two out of three of the testis-specific linker histones appear in the differentiation phase of spermatogenesis, in addition to the two classes of non-histone basic nucleoprotein, transition proteins and protamines. In oocytes, the transition to a tissue-specific linker histone, like in the case of histone $\mathrm{H} 1 \mathrm{t}$, appears to correlate with the advent of the meiotic phase and may involve the formation of a looser chromatin structure during this time. Since mitosis is a key feature in the cell cycle of somatic cells, it should come as no surprise that the mitotic phase of both spermatogenesis and oogenesis is characterized by the presence of somatic linker histone types.

\section{Mitotic phase}

In females, PGCs destined to form oocytes migrate to the developing ovaries, where they undergo mitosis during months 2 7 of gestation in humans to produce about 6 million primary oocytes. The oocytes are reported to have a complement of somatic linker histones at this stage, but these gradually disap-
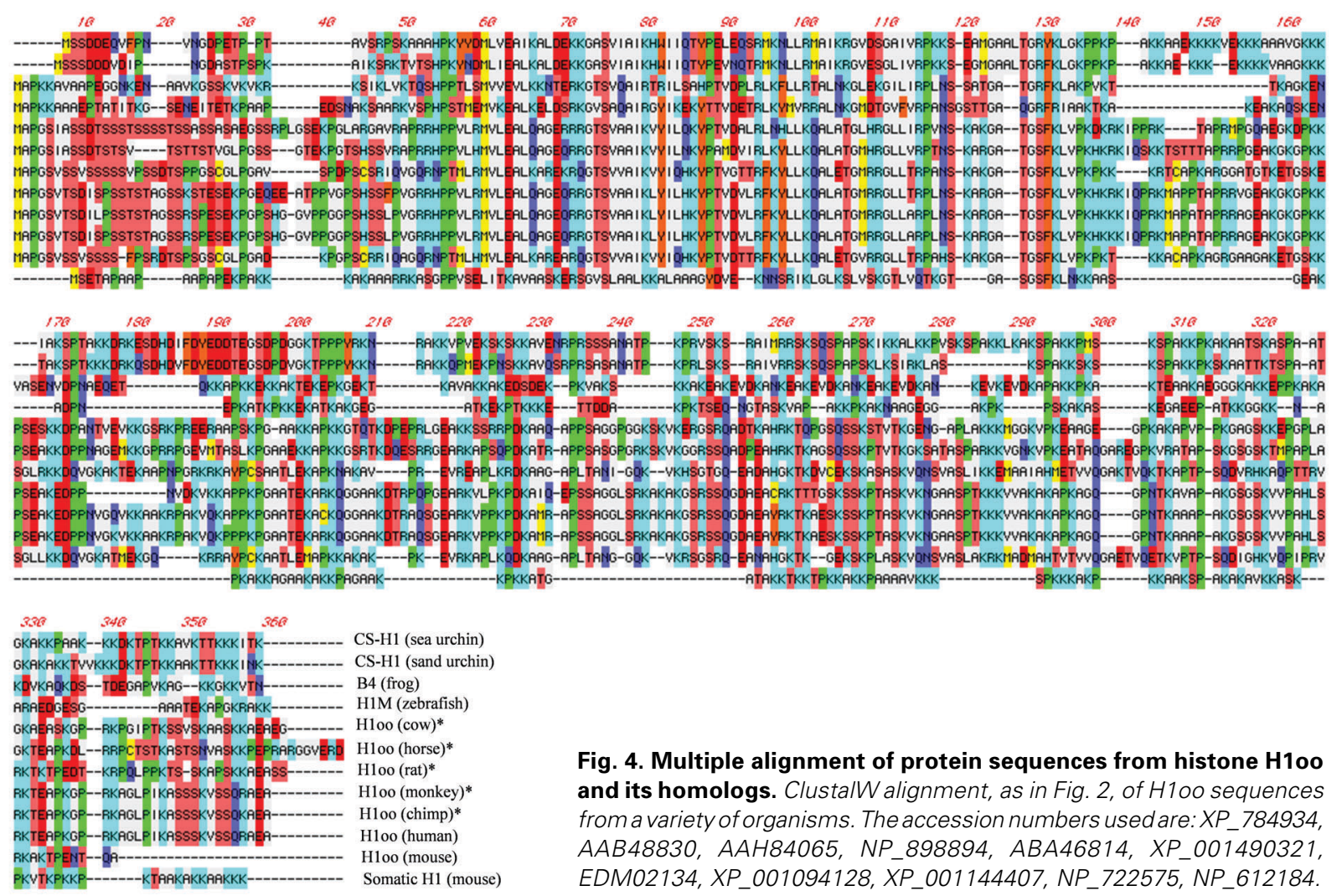

Fig. 4. Multiple alignment of protein sequences from histone $\mathrm{H} 100$ and its homologs. ClustalW alignment, as in Fig. 2, of H100 sequences from a variety of organisms. The accession numbers used are: $X P_{-}$784934, AAB48830, AAH84065, NP_898894, ABA46814, XP_001490321, EDM02134, XP_001094128, XP_001144407, NP_722575, NP_612184. 


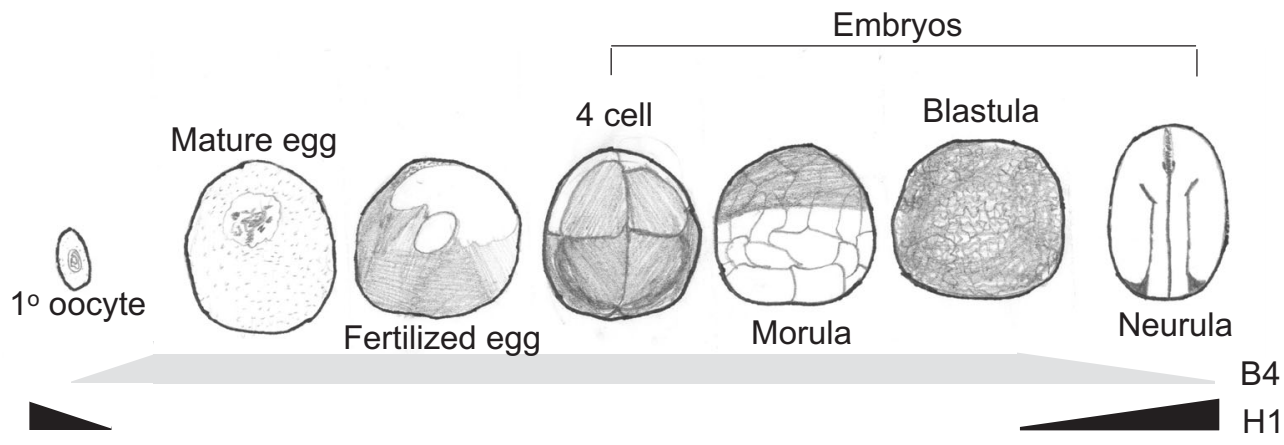

Fig. 5. Morphological changes during oogenesis and embryogenesis, along with known linker histone transitions. An overview of the major developmental changes which occur during the formation of oocytes in Xenopus, as well as during the early stages of embryogenesis. For simplicity, not all stages are shown. Morula, blastula, and neurula correspond to stages 6.5, 9, and 19 of embryogenesis, respectively. Bars representing histone levels are as in Fig. 1, B4 levels are indicated by a gray bar, while somatic $\mathrm{H} 1$ levels are indicated by a black bar. Illustration by Justin Godde.

pear after they exit the mitotic phase (Clarke et al., 1997). In contrast, the primordial cells have been reported to contain low levels of oocyte-specific linker histone expression, while this protein was found to be abundant in primary oocytes (Tanaka, M., et al., 2005, Fig. 5). While the Xenopus B4 protein if often described in the literature as appearing early in the meiotic phase, there no hard evidence of its absence in late-mitotic primary oocytes, early studies having only checked for B4 in this stage or later (Smith et al., 1988). Regardless of exactly when this protein first appears, suffice it to say that the oocyte-specific linker histone appears to be important for the transition from the mitotic to meiotic phase in both mammals and amphibians.

\section{Meiotic phase}

While spermatocytes undergo an exceptionally long prophase in their first meiotic division, primary oocytes become arrested at this phase in most animals, remaining in this state for vastly different amounts of time. In Xenopus, meiotic arrest lasts a little over a year, while in humans it lasts at least until puberty but can extend for nearly 50 years (Carlson, 1996). Unlike spermatocytes, however, oocytes progress through the leptotene, zygotene, and pachytene stages fairly quickly, and become arrested in the diplotene stage, which is normally quite brief in spermatocytes. The oocyte is surrounded at this time by a layer of protective follicular cells, and can be referred to as a primordial follicle (Carlson, 1996).

This is not to say that the oocyte lies completely dormant during diplotene arrest. During this phase, the oocyte begins the process of maturation, somewhat analogous to the differentiation phase of spermatogenesis. Here, chromosomes can be seen to decondense and become transcriptionally active following homologous recombination (Carlson, 1996). In amphibians, birds, and reptiles, the chromosomes take up an unusual conformation, called lampbrush chromosomes, that contain large chromatin loops which extend outward from the chromosomes. The lampbrush configuration, or simply chromosome decondensation in other animals, is coupled with an increase in transcription at all levels, producing large amounts of mRNA, rRNA, and tRNA (Carlson, 1996). A typical model for this transcription in Xenopus is the study of 5S rRNA expression, the number of genes of which have been increased by DNA amplification by this point (Crane-Robinson, 1999). The nucleus of the primary oocyte swells as it fills with RNA, especially in organisms which contain lampbrush chromosomes. In Xenopus, this large nucleus is called the germinal vesicle, and this stage of oogenesis is also referred to as GV (Carlson, 1996). Coupled with the enlargement of the nucleus, the cytoplasm of certain animals such as Xenopus begins to enlarge at this point, forming a yolk that is filled with lipids, polysaccharides, and RNA that has been transported there, some of which undergoes translation, but much of which is stored in an inactive form. Mammals, however, do not develop an appreciable yolk; mature human oocytes, for instance, reach a size of only $0.1 \mathrm{~mm}$ across, only one quarter the diameter of the nucleus in a Xenopus oocyte (Carlson, 1996; Fig. 5). Since it is during the diplotene stage of meiosis that oocyte-specific histones have their first discernable function in oogenesis, we will take up a discussion of them now.

In contrast to histone HILS1, the shortest of the linker histones to be characterized, the oocyte-specific histones are the longest $\mathrm{H} 1$ histones to be described, mostly owing to their exceptionally long C-terminal tails (Tanaka, Y., et al., 2003, Fig. 4). Like H1t, the lysine to arginine ratio is reduced below that of the somatic histones in the oocyte-specific histone, being approximately 2:1 in both mammalian forms of $\mathrm{H} 100$ described (Tanaka et al., 2001; Tanaka, Y., et al., 2003; Table 1). Phylogenetic analysis of this protein, however, shows that it is more closely related to H1T2 and $\mathrm{H} 1^{\circ}$ than it is to $\mathrm{H} 1 \mathrm{t}$ (Yan et al., 2003). Another feature that $\mathrm{H} 100$ shares with $\mathrm{H} 1 \mathrm{~T} 2$, but not $\mathrm{H} 1 \mathrm{t}$, is the presence of potential sites of phosphorylation (Tanaka et al., 2001). One unique feature of oocyte-specific linker histones is a relatively high level of acidic amino acids, compared with somatic histones. This is especially evident in histone B4, which has 36 aspartic and glutamic acid residues, almost all of which are localized in the extended Cterminal tail (Fig. 4). This is nearly half the number of basic amino acids contained throughout the protein. Because of these primary sequence differences with somatic $\mathrm{H} 1$, as well as the suspicion that B4 played role a significantly different role in vivo than somatic histones, our laboratory has devised a number of in vitro studies to study the differential effects of B4 binding to chromatin.

Using a dinucleosome which had been reconstituted in vitro on two 5S rRNA genes, the binding of B4 was compared to that of somatic H1 (Ura et al., 1996). Although both linker histones were able to protect internucleosomal linker DNA from digestion by nucleases, the stability of these structures varied (Ura et al., 1996). We developed a new chromatin assembly system using a linker histone chaperone, and subsequent studies revealed differences in these two linker histones' ability to restrict the accessibility of nucleases to the protected linker DNA, as well as revealing that histone B4 allows chromatin to be remodeled by ATP- 
dependent chromatin remodeling factors, while $\mathrm{H} 1$ does not (Saeki et al., 2005). We have continued these studies using in vitro reconstituted 12-mer nucleosomal arrays on a synthetic nucleosome positioning sequence which allows for differences in chromatin folding to be discerned. Using analytical centrifugation to measure levels of chromatin compaction, we have shown that histone $\mathrm{H} 1$ has a much wider array of interactions with chromatin, being able to either relax or condense chromatin arrays in a concentration dependent fashion (Godde and Ura, unpublished results). B4, on the other hand, was seen to display a much narrower range of interactions, usually folding chromatin arrays to a lesser extent, compared to the same concentration of $\mathrm{H} 1$.

Other groups have performed in vivo studies to address this same question. Recently, the mouse mammary tumor virus (MMTV) promoter was reconstituted in Xenopus oocytes to address the differential effect of linker histone binding to chromatin templates (Belikov et al., 2007). While the expression of H1A, the major somatic subtype in Xenopus, could be demonstrated as having been incorporated into chromatin, the effects that it had on hormone-dependent MMTV transcription proved concentration dependent. Subsaturating levels of $\mathrm{H} 1$ expression were seen to enhance transcription of this construct, while this hormone-dependent stimulation was lost at higher levels of expression (Belikov et al., 2007). Curiously, expression of histone B4, in contrast, did not affect either chromatin architecture or MMTV expression, suggesting a somatic histone $\mathrm{H} 1$ specific function in gene activation. Furthermore, the B4 protein failed to compete with histone $\mathrm{H} 1$ binding to chromatin in vivo (Belikov et al., 2007).

This failure to compete with somatic $\mathrm{H} 1$ leads us to ponder whether such a direct competition ever takes place in vivo during diplotene arrest, the time that is presumably crucial for such a replacement to take place. We have described the gradual disappearance of somatic $\mathrm{H} 1$ following the mitotic stage of oogenesis, and the available evidence supports its nearly complete absence from the oocyte by the time of meiosis arrest. While mRNA encoding for all six of the somatic subtypes of $\mathrm{H} 1$ could be detected in GV-stage oocytes of Xenopus, none of their corresponding proteins were found to be present using immunological techniques, with the exception of histone $\mathrm{H} 1^{\circ}$ (Hock et al., 1993; Clarke et al., 1997; Clarke et al., 1998; Fu et al., 2003). It was later shown that injected somatic $\mathrm{H} 1$ was not able to localize properly in mouse oocyte chromatin, compared to H1oo (Becker et al., 2005). Since the B4 protein has been shown to associate with the histone chaperone NAP-1 in Xenopus oocytes, the deposition of particular linker histone variants in vivo is likely to be regulated by histone $\mathrm{H} 1$-chaperone complexes rather than involve the direct replacement of subtypes on a large scale (Shintomi et al., 2005; Fig. 5).

Once cells, now called secondary follicles, are released from diplotene arrest, whether by the advent of puberty or by the completion of the first stages of maturation, they complete prophase I fairly rapidly and move on to the metaphase, where the chromosomes align down the middle of the cell. Surprisingly, it is at this stage, not diplotene arrest, that mouse oocytes will arrest in if depleted of $\mathrm{H} 100$. When GV oocytes were injected with antisense morpholino oligonucleotides against $\mathrm{H} 100$, two-thirds of the injected cells were seen to arrest in metaphase I (Furuya et al., 2007; Table 1). It is not clear, however, whether the injection of another $\mathrm{H} 1$ subtype could rescue this phenotype, as injection of exogenous $\mathrm{H} 100$ was seen to do, future genetic studies will be required to conclude whether $\mathrm{H} 100$ is truly essential for oocyte viability (Furuya et al., 2007). Irregardless, these data suggest that the oocyte-specific histone, while not absolutely required for the completion of prophase I, plays a role in the completion of metaphase. At anaphase I and telophase I which follow, the accompanying cytoplasmic division is unequal, creating the first polar body. It was the absence of such a polar body in oocytes lacking $\mathrm{H} 100$ that first led the above authors to suspect a stagespecific arrest had occurred (Furuya et al., 2007). The oocytes can now be called secondary oocytes, or alternately, tertiary follicles, as they enter their second round of meiosis. As the oocytes progress through meiosis II, they are ovulated in mammals, only to become arrested a second time, this time in metaphase II. This meiotic arrest, however, lasts nowhere near as long as the first one, as cells will be released from it upon fertilization.

\section{Fertilization}

After the union of sperm and egg, the protamine-bound sperm chromatin can be seen to decondense as the protamines are replaced by oocyte-specific histones; the swollen engulfed sperm nucleus is now called the male pronucleus (Carlson, 1996; Fig. 5). In sea urchin, where linker histones are not replaced by protamines during spermatogenesis, the sperm $\mathrm{H} 1$ can be seen to be phosphorylated at their $\mathrm{N}$-terminal tails before being replaced by the oocyte-specific linker histone (Mandl et al., 1997). The functions that the oocyte-specific linker histones play in the developing embryo at this point have not been determined with any certainty. It has been much easier to establish some of the things that these $\mathrm{H} 1$ variants do not do during early embryonic development. Depletion of B4 from Xenopus oocyte extracts, for instance, has demonstrated that the presence of this histone is not required for the assembly of morphologically normal pronuclei which are capable of DNA replication (Ohsumi et al., 1993; Dasso et al., 1994). Similar experiments also established that B4 did not contribute to the physiological spacing of nucleosomes (Dimitrov et al., 1994). It has been proposed, however, that the presence of an oocyte-specific histone in embryos may both facilitate the rapid DNA replication which takes place in early embryos as well as be involved in the resetting of the genome to produce a totipotent state (Clarke et al., 1998). We will address the first part of this hypothesis now, but will save the latter part for a bit later in our discussion. In early cleavage stage embryos from Xenopus, Sphase has been seen to last only 15 minutes or so, a time which lengthens considerably as B4 is progressively lost during development. The addition of exogenous somatic $\mathrm{H} 1$ at this point has been shown to inhibit the replication process by reducing the number of replication forks in sperm nuclei, while leaving the rate of fork progression unchanged (Lu et al., 1998). As in the abovedescribed experiments, however, immunodepletion of B4 had no apparent effect on DNA replication in Xenopus egg extracts (Lu et al., 1998). It may be true that an open chromatin conformation is required for prereplication complexes to form on sperm chromatin and that oocyte-specific histone $\mathrm{H} 1$ is simply serving a supporting role in chromatin stability.

While the male pronucleus undergoes the replacement of its protamine with oocyte-specific $\mathrm{H} 1$, the egg nucleus breaks its 
meiotic arrest and extrudes another polar body. Both pronuclei are free to enter S-phase at this point, during which they rapidly replicate their respective sets of DNA (Carlson, 1996). As they begin their first mitoses since early in their respective developmental processes, the pronuclei migrate towards one another in the cell and fuse together before they reach metaphase. The two sets of chromosomes then line up together, fully mixing the maternal and paternal chromosomes prior to separation into two nuclei (Carlson, 1996). Although little or no transcription can be detected during the first embryonic cleavage, histone mRNAs which have been blocked from being translated are apparently activated at this time (Teranishi et al., 2004). Following this point, the model systems we have been using to describe oogenesis differ widely from each other. In mouse, and presumably humans, most of the somatic histones make their reappearance following the next mitotic division, during the four-cell stage of embryogenesis (Fu et al., 2003). In Xenopus, however, oocyte-specific histone will remain the predominant linker histone until much later in development, at the mid-blastula transition, or MBT (Dimitrov et al., 1993; Fig. 5). Sea urchin, however, appears to be somewhat intermediate between these two extremes, while a histone called $\alpha-\mathrm{H} 1$ replaces $\mathrm{CS}-\mathrm{H} 1$ fairly quickly after fertilization, it is itself replaced by other somatic variants during the blastula stage (Mandl et al., 1997; Hock et al., 1993).

\section{Somatic nuclear transfer}

Whether DNA is introduced into an egg by fertilization or by SNT, the linker histone transitions which take place are quite similar. One proposed role played by oocyte-specific histones is the introduction of a totipotent state (Clarke et al., 1998; Saeki et al., 2005). While this question is difficult to ascertain in naturally fertilized embryos, it is more easily addressed in somatic nuclei which have been introduced into donor eggs in order to clone an organism or to produce embryonic stem cells. It has been fifty years since Xenopus became the first animal to be cloned using this technique, a finding that was largely ignored by the general public until Dolly the sheep ushered in the advent of mammalian SNT (Gurdon et al., 1958; Gurdon, 2006). One main difference between SNT and fertilization is that somatic $\mathrm{H1}$, not protamines, from the transferred nucleus must be replaced directly by oocytespecific histones. Experiments using SNT have led to a greater understanding of how this replacement process takes place. First, linker histone replacement can be seen to occur quite quicklymore than $80 \%$ of transferred mice nuclei displayed intense positive staining for $\mathrm{H} 100$ only 5 minutes after injection (Gao et al., 2004). Since the nuclear envelopes of transferred nuclei do not break down for approximately one hour, it does not appear that this is a prerequisite for histone replacement (Gao et al., 2004). Furthermore, the linker histone transitions observed appeared to be donor nucleus-independent, even to the extent that a mammalian nucleus introduced into Xenopus egg extracts underwent replacement with histone B4 (Miyamoto et al., 2007). It has been demonstrated that a molecular chaperone called nucleoplasmin acts in the selective removal of linker histones from donor nuclei (Dimitrov and Wolffe, 1996). Nucleoplasmin was later shown to play a role in nuclear reprogramming in mice as well (Burns et al., 2003).

Another finding in Xenopus was that histone $\mathrm{H} 1^{\circ}$ was released from donor chromatin preferentially in comparison with other somatic linker histones (Dimitrov and Wolffe, 1996). It is unclear why this particular linker histone shows preferential release, especially since it has been known for its relatively high affinity for DNA binding (Wellman et al., 1999). This finding, does, however, resolve seemingly contradictory results recently obtained from two different groups using a very similar approach. Both groups studied histone replacement using FRAP, fluorescence recovery after photobleaching, in mice somatic nuclei which had been introduced into oocytes by SNT. One group came to the surprising conclusion, based on what we have discussed above, that histone $\mathrm{H} 1 \mathrm{oo}$ binds to chromatin more tightly than somatic linker histones, while the earlier group had reached precisely the opposite conclusion (Teranishi et al., 2004; Becker et al., 2005). This inconsistency could possibly be explained by the specific somatic $\mathrm{H} 1$ that was used in comparison with $\mathrm{H} 100$. The early experiments compared the mobility of $\mathrm{H} 100$ with that of $\mathrm{H} 1.2$, reporting a $\mathrm{t}_{1 / 2}$ of recovery of about 22 seconds for the former and 29 seconds for the latter (Teranishi et al., 2004). Hence, the conclusion that $\mathrm{H} 100$ bound less tightly to chromatin than somatic $\mathrm{H} 1$ was upheld. The later studies, however, compared $\mathrm{H} 1^{\circ}$ mobility with $\mathrm{H} 100$, reporting a $t_{1 / 2}$ of about 6 seconds for the former and 32 seconds for the latter (Becker et al., 2005). Since the mobility of $\mathrm{H} 100$ in the two studies is roughly comparable, one might conclude that the $\mathrm{H}^{\circ}$ in these studies is actually binding more loosely to chromatin than expected, rather than the $\mathrm{H} 100$ binding more tightly. Although the study which used $\mathrm{H}_{1}^{\circ}$ for comparison was able to repeat their findings using somatic cells in addition to oocytes, a recent study which used FRAP to measure the mobility of $\mathrm{H} 1^{\circ}$ in somatic cells confirmed a relatively fast rate of exchange for this histone (Meshorer et al., 2006).

\section{Later development}

As development continues after fertilization or SMT, a series of synchronous cell divisions lead to an embryo which looks like a small mulberry, the morula stage (Carlson, 1996; Fig. 5 \& 6). In Xenopus, embryos between the 16- and 64-cell stages are considered to be morula. After this, the cell divisions begin to lose their synchronous character and the embryo soon develops a central cavity called a blastocoel (Carlson, 1996). The embryo has now entered the blastula stage, a process which occurs about 4 hours post fertilization in Xenopus. As the blastula grows towards the next major stage, the gastrula, in which the process of gastrulation begins, three major regions can be discerned: 1) cells forming the roof of the blastocoel which will go on to form the ectoderm, 2) cells in the interior of the blastocoel which will go on to form the endoderm, and 3) cells in an equatorial ring which will go on to form the mesoderm (Carlson, 1996). These primary germ layers will then undergo further restriction once the process of neural induction begins, bringing with it the formation of the neurula (Fig. 5 \& 6).

It is about 6 hours into development, and roughly halfway to the gastrula stage, that the Xenopus embryo reaches its final major linker histone replacement, the mid-blastula transition. This histone replacement, like the others we have discussed, takes place gradually. Ever since the early stages of embryonic cleavage, the level of B4 histone can be seen to slowly decrease, while the level of somatic histones slowly increase, in what has been observed 
at being a roughly reciprocal relationship (Ohsumi and Katagiri, 1991; Dimitrov et al., 1993; Saeki et al., 2005; Fig. 6). Certain embryonic genes, such as the oocyte-type 5S rRNA gene, are down-regulated at this time, while others, such as the somatic $5 S$ rRNA gene, are up-regulated. In vitro studies demonstrated that the addition of somatic $\mathrm{H} 1$ to chromatin resulted in chromatosomes being positioned directly over oocyte-type genes, thereby occluding transcription factor binding, while the same histone led to a different chromatosomal position on the somatic-type genes, leaving them exposed to factor binding (Ura et al., 1995; Sera et al., 1998). As expected, the injection of ribozymes which disrupt the histone $\mathrm{H} 1 \mathrm{~A}$ gene has been shown to prolong the expression of the oocyte $5 \mathrm{~S}$ rRNA gene during MBT, while the concurrent overexpression of another somatic histone had the opposite effect (Steinbach et al., 1997). A link between oocyte-specific histones and pluripotency was supported by the observation that the accumulation of somatic $\mathrm{H} 1$ was rate limiting for the loss of mesodermal competence in cells from the blastocoel cap which would normally have become ectoderm, but could be induced to form mesoderm by supplementing them with a specific growth factor (Steinbach et al., 1997). Again, it may be the overall chromatin conformation at this point that is most important and not the actual histone $\mathrm{H} 1$ variants themselves. Assuming that the binding of oocyte-specific linker histone leads to a more open chromatin state, the same effect could presumably be produced by the hyperdynamic binding of somatic $\mathrm{H} 1$. Indeed, it has recently been demonstrated that histone $\mathrm{H} 1^{\circ}$ binds loosely to chromatin in mouse ES (embryonic stem) cells and that cells in which the dynamic exchange of $\mathrm{H}^{\circ}$ is restricted display differentiation arrest (Meshorer et al., 2006). These studies compared the mobility of $\mathrm{H}^{\circ}$ in $\mathrm{ES}$ cells to that of $\mathrm{H} 3$ and $\mathrm{H} 2 \mathrm{~B}$, using FRAP, and found that the $t_{1 / 2}$ of recovery was about 8 seconds for the linker

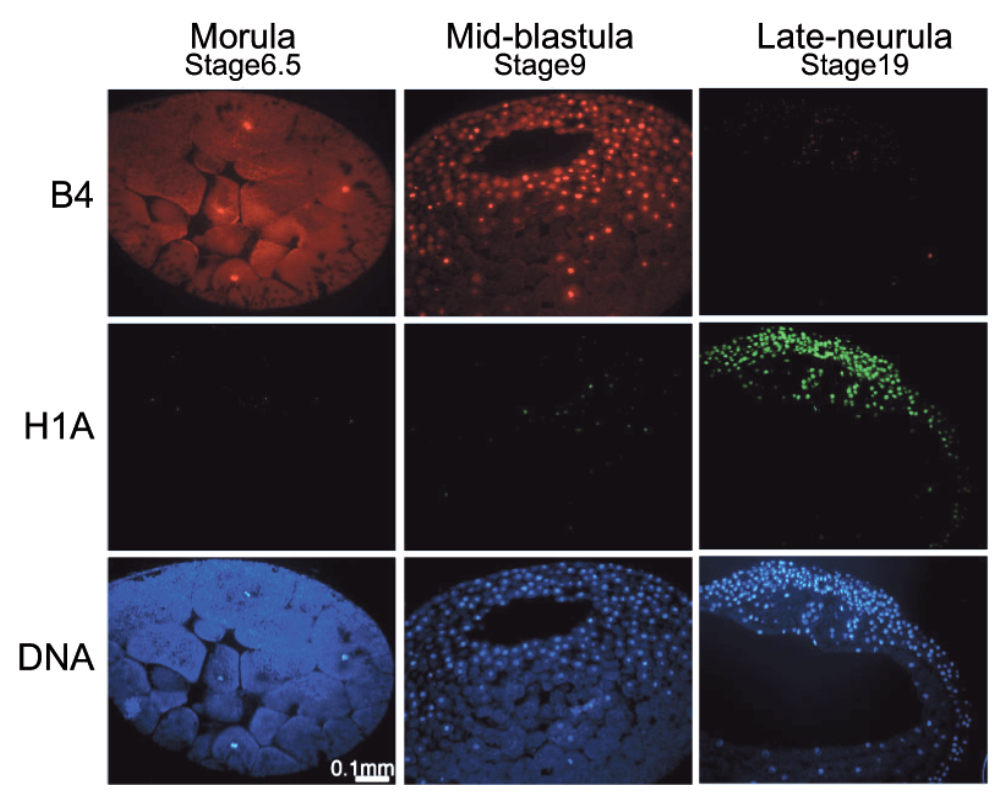

Fig. 6. Fluorescence microscopy demonstrating linker histone transitions during Xenopus embryogenesis. Cytological sections of Xenopus embryos at the indicated stage of development. Staining is with antibodies to either B4 or H1A, or with DAPI, which stains the DNA. Figure derived from Saeki et al., copyright (2005) National Academy of Sciences, USA., used with permission. histone, compared to 50 seconds for the core histones (Meshorer et al., 2006). These levels of mobility were then seen to decrease in differentiated cells (Meshorer et al., 2006).

\section{Summary}

We have portrayed the process of development as a series of linker histone replacements. Exactly how, or why, these replacements take place is still unclear, but the fact that they do occur throughout a wide range of metazoans suggests that they likely serve an important role. While we have primarily focused on the effects of linker histone variants on chromatin structure during this review, we realize that $\mathrm{H} 1$ may play functional, as well as structural, roles in development which have yet to be elucidated. One unexpected functional role for $\mathrm{H} 1$ that has been recently described is its ability to convey signals in the cell. In this case, the presence of $\mathrm{H} 1.2$ in the cytoplasm acted to induce apoptosis by promoting the release of cytochrome $\mathrm{C}$ from the mitochondria (Konishi et al., 2003). Previously unforeseen structural roles for linker histones have recently been described as well. For instance, $\mathrm{H} 1$ has been shown to exhibit a structural role in microtubule nucleation and organization in acentriolar plants (Hotta et al., 2007; Nakayama et al., 2008). It may thus turn out that linker histones play a number of roles in the cell which are independent of their incorporation into chromatin. We have tried to speculate above what the linker histone replacements in question may mean to chromatin structure, but recognize that more work will be required to elucidate their precise role in development.

We have detailed no less than seven replacement events, involving both linker histone variants as well as certain basic nonhistone proteins, which occur in the context of the male genome as it progresses through spermatogenesis, participates in the fertilization of an egg, and finally develops into a sexually mature organism that is able to begin the whole developmental process over again. Female genomes, in contrast, appear to go through a much simpler change in linker histone variants as they oscillate between somatic and oocyte-specific H1s. Certain similarities between the sexes are of note, however. For instance, both types of germ cells start development as PGCs with a complement of somatic histone $\mathrm{H} 1$. These then take separate paths in males and females to become mature sperm and egg cells, both becoming arrested during their respective meiotic phases and undergoing a transition from somatic linker histones to gamete-specific ones. In both cases, the gamete-specific linker histones have been noted for their lower affinity for nucleosome binding as well as their reduced ability to condense chromatin. The differentiation/maturation phases of these two gametes then take widely different amounts of time, with sperm becoming mature in months but eggs often taking decades. Upon fertilization, the sperm chromatin rapidly goes through its penultimate linker histone transition, this time accepting the $\mathrm{H} 1$ complement of the egg, thereby allowing the newly combined genome to ready itself for the process of embryogenesis. It is this replacement event which appears to be critical for «resetting» the genome during the establishment of a totipotent state and has therefore been a primary focus of research in our laboratory. The replacement of somatic $\mathrm{H} 1$ with oocyte-specific $\mathrm{H} 1$ can 
also be seen to accompany SNT, which further attests to the importance of this transition. A final replacement back to somatic subtypes then occurs with varying rapidity, depending on the species, but is often concomitant with the cellular differentiation that is associated with later stages of development.

\section{Acknowledgements}

We wish to thank Dr. Y. Kaneda, as well as members of our laboratory, Drs. H. Saeki and K. Ohsumi for helpful discussions. This work was supported by grants from the Ministry of Education, Culture, Sports, Science and Technology of Japan and the Takeda Science Foundation.

\section{References}

ALDER, D. and GOROVSKY, M.A. (1975). Electrophoretic analysis of liver and testis histones of the frog Rana pipiens. J. Cell Biol. 64: 389-397.

AUSIO, J. (2006). Histone variants- the structure behind the function. Brief. Funct. Gen. Prot. 5: 228-243.

BARRA, J.L., RHOUNIM, L., ROSSIGNO, J.L. and FAUGERON, G. (2000). Histone $\mathrm{H} 1$ is dispensable for methylation-associated gene silencing in Ascobolus immersus and essential for long life span. Mol. Cell. Biol. 20: 61-69.

BECKER, M., BECKER, A., MIYARA, F., HAN, Z., KIHARA, M., BROWN, D.T., HAGER, G.L., LATHAM, K., ADASHI, E.Y. and MISTELI, T. (2005). Differential in vivo binding dynamics of somatic and oocyte-specific linker histones in oocytes and during ES cell nuclear transfer. Mol. Biol. Cell 16: 3887-3895.

BELIKOV, S., ASTRAND, C. and WRANGE, O. (2007). Mechanism of histone H1stimulated glucocorticoid receptor DNA binding in vivo. Mol. Cell. Biol. 27: 23982410.

BROWN, D.T. (2001). Histone variants: are they functionally heterogeneous? Genome Biol. 2: reviews0006.1-0006.6.

BURNS, K.H., VIVEIROS, M.M., REN, Y., WANG, P., DEMAYO, F.J., FRAIL, D.E., EPPIG, J.J. and MATZUK, M.M. (2003) Roles of NPM2 in chromatin and nucleolar organization in oocytes and embryos. Science 300: 633-636.

CARLSON, B.M. (1996) Pattern's Foundations of Embryology 6th ed. New York: McGraw-Hill.

CATENA, R., RONFANI, L., SASSONE-CORSI, P. and DAVIDSON, I. (2006). Changes in intranuclear chromatin architecture induce bipolar nuclear localization of histone variant H1T2 in male haploid spermatids. Dev. Biol. 296: 231238.

CHO, C., WILLIS, W.D., GOULDING, E.H., JUNG-HA, H., YOUNG-CHUL, C., HECHT, N.B. and EDDY, E.M. (2001). Haploinsufficiency of protamine-1 or -2 causes infertility in mice. Nature Genet. 28: 82-86.

CHURIKOV, D., ZALENSKAYA, I.A. and ZALENSKY, A.O. (2004). Male germlinespecific histones in mouse and man. Cytogenet. Genome Res. 105: 203-214.

CLARKE, H.J., BUSTIN, M. and OBLIN, C. (1997). Chromatin modifications during oogenesis in the mouse: removal of somatic subtypes of histone $\mathrm{H} 1$ from oocyte chromatin occurs post-natally through a post-transcriptional mechanism. J. Cell Sci. 110: 477-487.

CLARKE, H.J., MCLAY, D.W. and MOHAMED, O.A. (1998). Linker histone transitions during mammalian oogenesis and embryogenesis. Dev. Genet. 22: 17-30.

COLE, K.D., YORK, R.G. and KISTLER W.S. (1984). The amino acid sequence of boar H1t, a testis-specific H1 histone variant. J. Biol. Chem. 259: 13695-13702.

CRANE-ROBINSON, C. (1999). How do linker histones mediate differential gene expression? BioEssays 21: 367-371.

DASSO, M., DIMITROV, S. and WOLFFE, A.P. (1994). Nuclear assembly is independent of linker histones. Proc. Natl. Acad. Sci. USA 91: 12477-12481.

DELUCIA, F., FARAONE-MENNELLA, M.R., D'ERME, M., QUESADA, P., CAIAFA, $P$. and FARINA, B. (1994). Histone-induced condensation of rat testis chromatin: testis-specific $\mathrm{H} 1 \mathrm{t}$ versus somatic $\mathrm{H} 1$ variants. Biochem. Biophys. Res. Commun. 198: 32-39.

DE, S., BROWN, D.T., HONG LU, Z., LENO, G.H., WELLMAN, S.E. and SITTMAN D.B. (2002). Histone $H 1$ variants differentially inhibit DNA replication through an affinity for chromatin mediated by their carboxyl-terminal domains. Gene 292: 173-181.
DIMITROV, S. and WOLFFE, A.P. (1996). Remodeling somatic nuclei in Xenopus laevis egg extracts: molecular mechanisms for the selective release of histones $\mathrm{H} 1$ and $\mathrm{H} 1^{\circ}$ from chromatin and the acquisition of transcriptional competence. EMBO J. 15: 5897-5906.

DIMITROV, S., ALMOUZNI, G., DASSO, M. and WOLFFE, A.P. (1993). Chromatin transitions during early Xenopus embryogenesis: changes in histone $\mathrm{H} 4$ acetylation and in linker histone type. Dev. Biol. 160: 214-227.

DIMITROV, S., DASSO, M.C. and WOLFFE, A.P. (1994). Remodeling sperm chromatin in Xenopus laevis egg extracts: the role of core histone phosphorylation and linker histone B4 in chromatin assembly. J. Cell Biol. 126: 591-601.

DRABENT, B., SAFTIG, P., BODE, C. and DOENECKE, D. (2000). Spermatogenesis proceeds normally in mice without linker histone H1t. Histochem. Cell Biol. 113: 433-442.

FAN, Y., NIKITINA, T., MORIN-KENSICKI, E.M., ZHAO, J., MAGNUSON, T.R., WOODCOCK, C.L. and SKOULTCHI, A.I. (2003). H1 linker histones are essential for mouse development and affect nucleosome spacing in vivo. Mol. Cell. Biol. 23: 4559-4572.

FAN, Y., NIKITINA, T., ZHAO, J., FLEURY, T.J., BHATTACHARYYA, R., BOUHASSIRA, E.E., STEIN, A., WOODCOCK, C.L. and SKOULTCHI, A.I. (2005). Histone $\mathrm{H} 1$ depletion in mammals alters global chromatin structure but causes specific changes in gene regulation. Cell 123: 1199-1212.

FAN, Y., SIROTKIN, A., RUSSELL, R.G., AYALA, J. and SKOULTCHI, A.I. (2001). Individual somatic $\mathrm{H} 1$ subtypes are dispensable for mouse development even in mice lacking the $\mathrm{H}^{\circ}{ }^{\circ}$ replacement subtype. Mol. Cell. Biol. 21: 7933-7943.

FANTZ, D.A., HATFIELD, W.R., HORVATH, G., KISTLER, M.K. and KISTLER, W.S. (2001). Mice with a targeted disruption of the H1t gene are fertile and undergo normal changes in structural chromosomal proteins during spermiogenesis. Biol. Reprod. 64: 425-431.

FLENNIKEN, A.M. and NEWROCK, K.M. (1987). H1 Histone subtypes and subtype synthesis switches of normal and delobed embryos of llyanassa obsoleta. Dev. Biol. 124: 457-468.

FU, G., GHADAM, P., SIROTKIN, A., KHOCHBIN, S., SKOULTCHI, A.I. and CLARKE, H.J. (2003). Mouse oocytes and early embryos express multiple histone H1 subtypes. Biol. Reprod. 68: 1569-1576.

FURUYA, M., TANAKA, M., TERANISHI, T., MATSUMOTO, K., HOSOI, Y., SAEKI, K., ISHIMOTO, H., MINEGISHI, K., IRITANI, A. and YOSHIMURA, Y. (2007) $\mathrm{H} 1$ foo is indispensable for meiotic maturation of the mouse oocyte. J. Reprod. Dev. 53: 895-902.

GAO, S., CHUNG, Y.G., PARSEGHIAN, M.H., KING, G.J., ADASHI, E.Y. and LATHAM, K.E. (2004). Rapid H1 linker histone transitions following fertilization or somatic cell nuclear transfer: evidence for a uniform developmental program in mice. Dev. Biol. 266: 62-75

GODDE, J.S. and URA, K. (2008). Cracking the enigmatic linker histone code. J. Biochem. 143: 287-293.

GURDON, J.B. (2006). From nuclear transfer to nuclear reprogramming: the reversal of cell differentiation. Annu. Rev. Cell Dev. Biol. 22: 1-22.

GURDON, J.B., ELSDALE, T.R. and FISCHBERG, M. (1958). Sexually mature individuals of Xenopus laevis from the transplantation of single somatic nuclei. Nature 182: 64-65.

HOCK, R., MOORMAN, A., FISCHER, D. and SCHEER, U. (1993). Absence of somatic histone $\mathrm{H} 1$ in oocytes and preblastula embryos of Xenopus laevis. Dev. Biol. 158: 510-522.

HOTTA, T., HARAGUCHI, T. and MIZUNO, K. (2007). A novel function of plant histone $\mathrm{H} 1$ : microtubule nucleation and continuous plus end association. Cell Struct. Funct. 32: 79-87.

IGUCHI, N., TANAKA, H., YAMADA, S., NISHIMURA, H. and NISHIMUNE, Y. (2004). Control of mouse hils1 gene expression during spermatogenesis: identification of regulatory element by transgenic mouse. Biol. Reprod. 70 : 1239-1245.

JEDRUSIK, M.A. and SCHULZE, E. (2001). A single histone H1 isoform (H1.1) is essential for chromatin silencing and germline development in Caenorhabditis elegans. Development 128: 1069-1080.

JEDRZEJCZAK, P., KEMPISTY, B., BRYJA, A., MOSTOWSKA, M., DEPAMARTYNOW, M., PAWELCZYK, L. and JAGODZINSKI, P.P. (2007). Quantitative assessment of transition proteins 1,2 spermatid-specific linker histone $\mathrm{H} 1$ like protein transcripts in spermatozoa from normozoospermic and 
asthenozoospermic men. Arch. Androl. 53: 199-205.

JERZMANOWSKI, A. (2007). SWI/SNF chromatin remodeling and linker histones in plants. Biochim. Biophys. Acta 1769: 330-345.

KHADAKE, J.R. and RAO, M.R. (1995). DNA- and chromatin-condensing propertied of rat testes $\mathrm{H} 1 \mathrm{a}$ and $\mathrm{H} 1 \mathrm{t}$ compared to those of rat liver $\mathrm{H} 1 \mathrm{bdec} ; \mathrm{H} 1 \mathrm{t}$ is a poor condenser of chromatin. Biochemistry 34: 15792-15801.

KHOCHBIN, S. (2001) Histone $\mathrm{H} 1$ diversity: bridging regulatory signals to linker histone function. Gene 271: 1-12.

KHOCHBIN, S. and WOLFFE, A.P. (1994). Developmentally regulated expression of linker-histone variants in vertebrates. Eur. J. Biochem. 225: 501-510.

KONISHI, A., SHIMIZU, S., HIROTA, J., TAKAO, T., FAN, Y., MATSUOKA, Y., ZHANG, L., YONEDA, Y., FUJII, Y., SKOULTCHI, A.I. and TSUJIMOTO (2003). Involvement of histone $\mathrm{H} 1.2$ in apoptosis induced by DNA double-strand breaks. Cell 114: 673-688.

KORNBERG, R.D. (1974). Chromatin structure: a repeating unit of histones and DNA. Science 184: 868-871.

KORNBERG, R.D. and LORCH, Y. (1999). Twenty-five years of the nucleosome, fundamental particle of the eukaryote chromosome. Cell 98: 285-294.

LENNOX, R.W. and COHEN, L.H. (1984). The alterations in $\mathrm{H} 1$ histone complement during mouse spermatogenesis and their significance for $\mathrm{H} 1$ subtype function. Dev. Biol. 103: 80-84.

LEWIS, J.D., SAPERAS, N., SONG, Y., ZAMORA, M.J., CHIVA, M. and AUSIO, J. (2004). Histone $\mathrm{H} 1$ and the origin of protamines. Proc. Natl. Acad. Sci. USA 101: 4148-4152.

LIN, Q., INSELMAN, A., HAN, X., XU, H., ZHANG, W., HANDEL, M.A. and SHOULTCHI, A.I. (2004). Reduction in linker histone levels are tolerated in developing spermatocytes but cause changes in specific gene expression. $J$. Biol. Chem. 279: 23525-23535.

LIN, Q., SIROTKIN, A. and SKOULTCHI, A.I. (2000). Normal spermatogenesis in mice lacking the testis-specific linker histone H1t. Mol. Cell. Biol. 20: 2122-2128.

LU, Z.H., SITTMAN, D.B., ROMANOWSKI, P. and LENO, G.H. (1998). Histone H1 reduces the frequency of initiation in Xenopus egg extract by limiting the assembly of prereplication complexes on sperm chromatin. Mol. Biol. Cell 9: 1163-1176

MANDL, B., BRANDT, W.F., SUPERTI-FURGA, G., GRANINGER, P.G., BIRNSTIEL, M.L. and BUSSLINGER, M. (1997). The five cleavage-stage (CS) histones of the sea urchin are encoded by a maternally expressed family of replacement histone genes: functional equivalence of the $\mathrm{CS} \mathrm{H} 1$ and frog $\mathrm{H} 1 \mathrm{M}$ (B4) proteins. Mol. Cell. Biol. 17: 1189-1200.

MARTIANOV, I., BRANCORSINI, S., CATENA, R., GANSMULLER, A., KOTAJA, N., PARVINEN, M., SASSONE-CORSI, P. and DAVIDSON, I. (2005). Polar nuclear localization of $\mathrm{H} 1 \mathrm{~T} 2$, a histone $\mathrm{H} 1$ variant, required for spermatid elongation and DNA condensation during spermiogenesis. Proc. Natl. Acad. Sci. USA 102: 2808-2813.

MEISTRICH, M.L., BUCCI, L.R., TROSTLE-WEIGE, P.K. and BROCK, W.A. (1985). Histone variants in rat spermatogonia and primary spermatocytes. Dev. Biol. 112: 230-240.

MESHORER, E., YELLAJOSHULA, D., GEORGE, E., SCAMBLER, P.J., BROWN, D.T. and MISTELI, T. (2006). Hyperdynamic plasticity of chromatin proteins in pluripotent embryonic stem cells. Dev. Cell 10: 105-116.

MIYAMOTO, K., FURUSAW, T., OHNUKI, M. GOEL, S., TOKUNAGA, T., MINAMI, N., YAMADA, M., OHSUMI, K. and IMAI, H. (2007). Reprogramming events of mammalian somatic cells induced by Xenopus laevis egg extracts. Mol. Reprod. Dev. 74: 1268-1277.

MULLER, K., THISSE, C., THISSE, B. and RAZ, E. (2002). Expression of a linker histone-like gene in the primordial germ cells in zebrafish. Mech. Dev. 117: 253257.

NAKAYAMA, T., ISHII, T., HOTTA, T. and MIZUNO, K. (2008). Radial microtubule organization by histone $\mathrm{H} 1$ on nuclei of cultured tobacco BY-2 cells. J. Biol. Chem. 283: 16632-16640.

OKO, R.J., JANDO, V., WAGNER, C.L., KISTLER, W.S. and HERMO, L.S. (1996). Chromatin reorganization in rat spermatids during the disappearance of testisspecific histone, $\mathrm{H} 1 \mathrm{t}$, and the appearance of transition proteins TP1 and TP2. Biol. Reprod. 54: 1141-1157.

OHSUMI, K. and KATAGIRI, C. (1991) Occurrence of H1 subtypes specific to pronuclei and cleavage-stage cell nuclei of anuran amphibians. Dev. Biol. 147: 110-120.

OHSUMI, K., KATAGIRI, C. and KISHIMOTO, T. (1993) Chromosome condensation in Xenopus mitotic extracts without histone H1. Science 262: 2033-2035

OUDET, P., GROSS-BELLARD, M. and CHAMBON, P. (1975). Electron microscopic and biochemical evidence that chromatin structure is a repeating unit Cell 4: 281-300

PRADEEPA, M.M. and RAO, M.R.S. (2007) Chromatin remodeling during mammalian spermatogenesis: role of testis specific histone variants and transition proteins. Soc. Reprod. Fertil. Suppl. 63: 1-10.

PRYMAKOWSKA-BOSAK, M., PRZEWTOKA, M.R., SLUSARCZYK, J., KURAS, M., LICHOTA, J., KILIANCZYK, B., JERZMANOWSKI, A. (1999). Linker histones play a role in male meiosis and the development of pollen grains in tobacco. Plant Cell 11: 2317-2329.

RABINI, S., FRANKE, K., SAFTIG, P., BODE, C., DOENECKE, D. and DRABENT, B. (2000). Spermatogenesis in mice is not affected by histone $\mathrm{H} 1.1$ deficiency. Exp. Cell Res. 255: 114-124.

RAJA, S.J. and RENKAWITZ-POHL, R. (2005). Replacement by Drosophila melanogaster protamines and Mst77F of histones during chromatin condensation in late spermatids and role of sesame in the removal of these proteins from the male pronucleus. Mol. Cell. Biol. 25: 6165-6177.

RAMAKRISHNAN, V. (1997). Histone structure and the organization of the nucleosome. Annu. Rev. Biophys. Biomol. Struct. 26: 83-112.

RAMESH, S., BHARATH, M.M.S., CHANDRA, N.R. and RAO, M.R.S. (2006). A $\mathrm{K} 52 \mathrm{Q}$ substitution in the globular domain of histone $\mathrm{H} 1 \mathrm{t}$ modulates its nucleosome binding properties. FEBS Lett. 580: 5999-6006.

RAMON, A., MURO-PASTOR, M.I., SAZZOCCHIO, C. and GONZALEZ, R. (2000). Deletion of the unique gene encoding a typical histone $\mathrm{H} 1$ has no apparent phenotype in Aspergillus nidulans. Mol. Microbiol. 35: 223-233.

RUSSELL, L.D., ETTLIN, R.A., SINHA HIKIM, A.P. and CLEGG, E.D. (1990) Histological and Histopathological Evaluation of the Testis. Clearwater, FL: Cache River Press.

RUDERMAN, J.V. and GROSS, P.R. (1974). Histones and histone synthesis in sea urchin development. Dev. Biol. 36: 286-298.

SAEKI, H., OHSUMI, K., AIHARA, H., ITO, T., HIROSE, S., URA, K. and KANEDA, Y. (2005). Linker histone variants control chromatin dynamics during early embryogenesis. Proc. Natl. Acad. Sci. USA 102: 5697-5702.

SCHWARZ, P.M., FELTHAUSER, A., FLETCHER, T.M. and HANSEN, J.C. (1996). Reversible oligonucleosome self-association: dependence on divalent cations and core histone tail domains. Biochemistry 35: 4009-4015.

SERA, T. and WOLFFE, A.P. (1998). Role of histone $\mathrm{H} 1$ as an architectural determinant of chromatin structure and as a specific repressor of transcription on Xenopus oocyte 5S rRNA genes. Mol. Cell. Biol. 18: 3668-3680.

SEYEDIN, S.M., COLE, R.D. and KISTLER, W.S. (1981) H1 histones from mammalian testes. The widespread occurrence of H1t. Exp. Cell Res. 136: 399-405.

SEYEDIN, S.M. and KISTLER, W.S. (1980). Isolation and characterization of rat testis $\mathrm{H} 1 \mathrm{t}$. An $\mathrm{H} 1$ histone variant associated with spermatogenesis. J. Biol. Chem. 255: 5949-5954

SHEN, X., YU, L., WEIR, J.W. and GOROVSKY, M.A. (1995). Linker histones are not essential and affect chromatin condensation in vivo. Cell 82: 47-56.

SHINTOMI, K., IWABUCHI, M., SAEKI, H., URA, K., KISHIMOTO, T. and OHSUMI, K. (2005). Nucleosome assembly protein-1 is a linker histone chaperone in Xenopus eggs. Proc. Nat. Acad. Sci. USA 102: 8210-8215.

SHIRES, A., CARPENTER, M.P. and CHALKLEY, R. (1975). New histones found in mature mammalian testes. Proc. Nat. Acad. Sci. USA 72: 2714-2718.

SIROTKIN, A.M., EDELMANN, W., CHENG, G., KLEIN-SZANTO, A., KUCHERLAPATI, R. and SKOULTCHI, A.I. (1995). Mice develop normally without the $\mathrm{H}^{\circ}{ }^{\circ}$ linker histone. Proc. Natl. Acad. Sci. USA 92: 6434-6438.

SMITH, R.C., DWORKIN-RASTL, E. and DWORKIN, M.B. (1988). Expression of a histone $\mathrm{H} 1$-like protein is restricted to early Xenopus development. Genes Dev. 2: $1284-1295$.

STEINBACH, O.C., WOLFFE, A.P. and RUPP, R.A.W. (1997). Somatic linker histones cause loss of mesodermal competence in Xenopus. Nature 389: 395399

STRAHL, B.D. and ALLIS, C.D. (2000). The language of covalent histone modifi- 
cations. Nature 403: 41-45.

TALASZ, H., SAPOJNIKOVAS, N., HELLIGER, W., LINDNER, H. and PUSCHENDORF, B. (1998). In vitro binding of $\mathrm{H} 1$ histone subtypes to nucleosomal organized mouse mammary tumor virus long terminal repeat promoter. J. Biol. Chem. 273: 32236-32243.

TANAKA, H., IGUCHI, N., ISOTANI, A., KITAMURA, K., TOYAMA, Y., MATSUOKA, Y., ONISHI, M., MASAI, K., MAEKAWA, M., TOSHIMORI, K., OKABE, M. and NISHIMUNE, Y. (2005). HANP1/H1T2, a novel histone H1-like protein involved in nuclear formation and sperm fertility. Mol. Cell. Biol. 25: 7107-7119.

TANAKA, M., HENNEBOLD, J.D., MACFARLANE, J. and ADASHI, E.Y. (2001). A mammalian oocyte-specific linker histone gene $\mathrm{H} 100$ : homology with the genes for the oocyte-specific cleavage stage histone (cs-H1) of sea urchin and the B4/ $\mathrm{H} 1 \mathrm{M}$ histone of the frog. Development 128: 655-664.

TANAKA, M., KIHARA, M., HENNEBOLD, J.D., EPPIG, J.J., VIVEIROS, M.M., EMERY, B.R., CARRELL, D.T., KIRKMAN, N.J., MECZEKALSKI, B., ZHOU, J., BONDY, C.A., BECKER, M., SCHULTZ, R.M., MISTELI, T., DE LA FUENTE, R., KING, G.J. and ADASHI, E.Y. (2005). H1FOO is coupled to the initiation of oocytic growth. Biol. Reprod. 72: 135-142.

TANAKA, M., KIHARA, M., MECZEKALSKI, B., KING, G.J. and ADASHI, E.Y. (2003). H100: a pre-embryonic $\mathrm{H} 1$ linker histone in search of a function. Mol. Cell. Endocrinol. 202: 5-9.

TANAKA, Y., KATO, S., TANAKA, M., KUJI, N. and YOSHIMURA, Y. (2003). Structure and expression of the human oocyte-specific histone $\mathrm{H} 1$ gene elucidated by direct RT-nested PCR of a single oocyte. Biochem. Biophys. Res. Commun. 304: 351-357.

TERANISHI, T., TANAKA, M., KIMOTO, S., ONO, Y., MIYAKOSHI, K., KONO, T. and YOSHIMURA, Y. (2004). Rapid replacement of somatic linker histones with the oocyte-specific linker histone $\mathrm{H} 1$ foo in nuclear transfer. Dev. Biol. 266: 7686.

TRIESCHMANN, L., SCHULZE, E., SCHULZE, B. and GROSSBACH, U. (1997). The histone $\mathrm{H} 1$ genes of the dipteran insect, Chironomus thummi, fall under two divergent classes and encode proteins with distinct intranuclear distribution and potentially different functions. Eur. J. Biochem. 250: 184-196.

URA, K., HAYES, J.J. and WOLFFE, A.P. (1995). A positive role for nucleosome mobility in the transcriptional activity of chromatin templates: restriction by linker histone. EMBO J. 14: 3752-3765.

URA, K., NIGHTINGALE, K. and WOLFFE, A.P. (1996). Differential association of HMG1 and linker histones B4 and $\mathrm{H} 1$ with dinucleosomal DNA: structural transitions and transcriptional repression. EMBO J. 15: 4959-4969.

USHINSHY, S.C., BUSSEY, H., AHMED, A.A., WANG, Y., FRIESEN, J., WILLIAMS, B.A. and STORMS, R.K. (1997). Histone H1 in Saccharomyces cerevisiae. Yeast 13: 151-161.

WELLMAN, S.E., SONG, Y. and MAMOON, N.M. (1999). Sequence preference of mouse $\mathrm{H} 1^{\circ}$ and $\mathrm{H} 1$ t. Biochemistry 38: 13112-13118.

WIBRAND, K. and OLSEN, L.C. (2002). Linker histone H1M transcripts mark the developing germ line in zebrafish. Mech. Dev. 117: 249-252.

WIERZBICKI, A.T. and JERZMANOWSKI, A. (2005). Suppression of histone H1 genes in Arabidopsis results in heritable developmental defects and stochastic changes in DNA methylation. Genetics 169: 997-1008.

YAN, W., MA, L., BURNS, K.H. and MATZUK, M.M. (2003). HILS1 is a spermatidspecific linker histone $\mathrm{H} 1$-like protein implicated in chromatin remodeling during mammalian spermiogenesis. Proc. Natl. Acad. Sci. USA 100: 10546-10551.

YU, Y.E., ZHANG, Y., UNNI, E., SHIRLEY, C.R., DENG, J.M., RUSSELL, L.D., WEIL, M.M., BEHRINGER, R.R. and MEISTRICH, M.L. (2000). Abnormal spermatogenesis and reduced fertility in transition nuclear protein 1-deficient mice. Proc. Natl. Acad. Sci. USA 97: 4683-4688.

ZHAO, M., SHIRLEY, C.R., HAYASHI, S., MARCON, L., BHAGYALAXMI, M., SUGANUMA, R., BEHRINGER, R.R., BOISSONNEAULT, G., YANAGIMACHI, R. and MEISTRICH, M.L. (2004). Transition nuclear proteins are required for normal chromatin condensation and functional sperm development. Genesis 38: 200-213.

ZHAO, M., SHIRLEY, C.R., YU, E., MOHAPATRA, B., ZHANG, Y., UNNI, E., DENG, J.M., ARANGO, N.A., TERRY, N.H.A., WEIL, M.M., RUSSELL, L.D., BEHRINGER, R.R. and MEISTRICK, M.L. (2001). Targeted disruption of the transition protein 2 gene affects sperm chromatin structure and reduces fertility in mice. Mol. Cell. Biol. 21: 7243-7255. 


\section{Further Related Reading, published previously in the Int. J. Dev. Biol.}

See our recent Special Issue Fertilization, in honor of David L. Garbers and edited by Paul M. Wassarman and Victor D. Vacquier at: http://www.ijdb.ehu.es/web/contents.php?vol=52\&issue=5-6

\section{A histone $\mathrm{H} 1$ variant is required for erythrocyte maturation in medaka Osamu Matsuoka, Norihisa Shindo, Daisuke Arai and Toru Higashinakagawa Int. J. Dev. Biol. (2008) 52: 887-892}

Dynamic distribution of the replacement histone variant $\mathrm{H} 3.3$ in the mouse oocyte and preimplantation embryos Maria-Elena Torres-Padilla, Andrew J. Bannister, Paul J. Hurd, Tony Kouzarides and Magdalena Zernicka-Goetz Int. J. Dev. Biol. (2006) 50: 455-461

Structural and functional properties of linker histones and high mobility group proteins in polytene chromosomes. J R Wisniewski and U Grossbach Int. J. Dev. Biol. (1996) 40: 177-187

Organization and expression of the developmentally regulated $\mathrm{H1}(\mathrm{O})$ histone gene in vertebrates.

D Doenecke and A Alonso

Int. J. Dev. Biol. (1996) 40: 395-401

Structural and functional properties of linker histones and high mobility group proteins in polytene chromosomes.

J R Wisniewski and U Grossbach

Int. J. Dev. Biol. (1996) 40: 177-187

Spermatogenesis in Drosophila.

W Hennig

Int. J. Dev. Biol. (1996) 40: 167-176

Developmentally regulated chromatin acetylation and histone $\mathrm{H1}(0)$ accumulation. D Seigneurin, D Grunwald, J J Lawrence and S Khochbin Int. J. Dev. Biol. (1995) 39: 597-603

Histone H1c decreases markedly in postreplicative stages of chicken spermatogenesis. $J$ Boix and C Mezquita

Int. J. Dev. Biol. (1991) 35: 43-48

2006 ISI **Impact Factor $=3.577^{* *}$

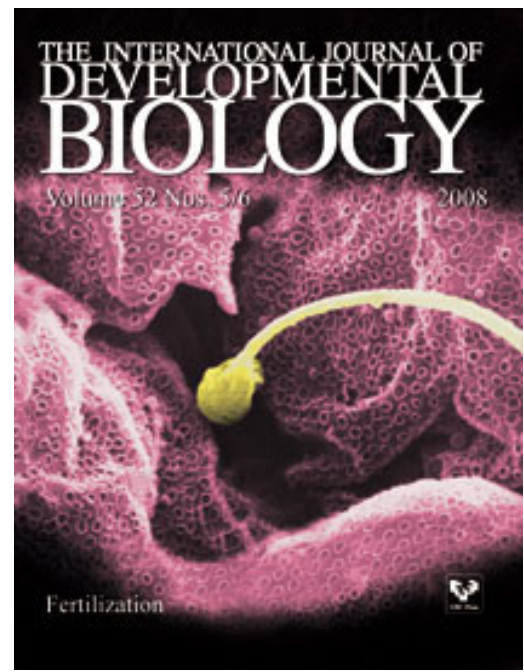

